\title{
To Meat or Not to Meat? New Perspectives on Neanderthal Ecology
}

\author{
Luca Fiorenza, ${ }^{1 *}$ Stefano Benazzi, ${ }^{2,3}$ Amanda G. Henry, ${ }^{4}$ Domingo C. Salazar-García, $3,4,5,6$ \\ Ruth Blasco, ${ }^{7}$ Andrea Picin, ${ }^{8,9,10}$ Stephen Wroe, ${ }^{11}$ and Ottmar Kullmer ${ }^{12}$ \\ ${ }^{1}$ Earth Sciences, University of New England, Armidale, NSW 2351, Australia \\ ${ }^{2}$ Department of Cultural Heritage, University of Bologna, Ravenna 48121, Italy \\ ${ }^{3}$ Department of Human Evolution, Max Planck Institute for Evolutionary Anthropology, Leipzig 04103, Germany \\ ${ }^{4}$ Plant Foods in Hominin Dietary Ecology Research Group, Max Planck Institute for Evolutionary Anthropology, \\ Leipzig 04103, Germany \\ ${ }^{5}$ Department of Archaeology, University of Cape Town, 7700 Rondebosch, South Africa \\ ${ }^{6}$ Department de Prehistòria i Arqueologia, Universitat de València, Valencia 46010, Spain \\ ${ }^{7}$ The Gibraltar Museum, 18-20 Bomb House Lane, PO Box 939, Gibraltar \\ ${ }^{8}$ Department of Prehistory and Early History, Friedrich Schiller Universität Jena, Jena, o7743 Germany \\ ${ }^{9}$ Neanderthal Museum, Mettmann, 40822 Germany \\ ${ }^{10}$ Institut Català de Paleoecologia Humana i Evolució Social (IPHES), Tarragona, 43007, Spain \\ ${ }^{11}$ Zoology, University of New England, Armidale, NSW 2351, Australia \\ ${ }^{12}$ Senckenberg Research Institute, 60325 Frankfurt am Main, Hessen, Germany
}

KEY WORDS zooarchaeology; stable isotopes; dental calculus; tooth wear; paleopathology; technology

ABSTRACT Neanderthals have been commonly
depicted as top predators who met their nutritional
needs by focusing entirely on meat. This information
mostly derives from faunal assemblage analyses and sta-
ble isotope studies: methods that tend to underestimate
plant consumption and overestimate the intake of ani-
mal proteins. Several studies in fact demonstrate that
there is a physiological limit to the amount of animal

In this manuscript, we review traditional as well as more recent approaches for reconstructing the diet in past human populations, and we show how new archaeological discoveries and innovative methods are changing our views of Neanderthal ecology and behavior. We further underline the importance of reconstructing Neanderthal environments derived from palaeoecological data to better understand and interpret the dietary evidence obtained by these methods. Finally, since the intake of specific foods can be invisible to certain techniques and detect by others, we suggest using a more holistic approach by integrating the findings of more than one method. Such comprehensive analyses would enable the reconstruction of the whole dietary spectrum, which is particularly important for species like Neanderthal, who lived under severe and unstable climatic conditions.

Neanderthals are undoubtedly the most studied and best-known group in the human fossil record. Despite that, for more than 100 years since their discovery, research on Neanderthal ecology, subsistence strategies, and diet have received remarkably little attention (Ready, 2010). It is only with the emergence of new archeological disciplines and development of innovative analytical approaches in the 1960s, that scholars began to look at Neanderthal behavior and adaptations to their environment. Methods such as faunal analysis, lithic technology, and taphonomic studies progressively led to a general portrait that defined Neanderthals as a homoge- proteins that can be consumed: exceeding these values causes protein toxicity that can be particularly dangerous to pregnant women and newborns. Consequently, to avoid food poisoning from meat-based diets, Neanderthals must have incorporated alternative food sources in their daily diets, including plant materials as well. Yrbk Phys Anthropol 156:43-71, 2015. ( 2014 American Association of Physical Anthropologists nous group, with similar nutritional needs typified by a reliance on the consumption of terrestrial animals. This idea was reinforced by the study of stable isotopes and Neanderthal anatomy. The general robusticity of Neanderthal skeletons, with relatively short limbs and heavy trunks, has been interpreted as adaptation to cold stress environments that follow the ecogeographic principles of Bergmann's and Allen's rules (e.g., Trinkaus, 1981; Ruff,

Grant sponsor: Australian Research Council; Grant number: DP140102659; Grant sponsor: the University of New England (UNE Research Seed Grant 2014); Grant sponsor: UNE Partnerships and University of New England (Career Development Award for Early Career Researchers); Grant sponsor: German Research Foundation; Grant number: FOR771, publication number 69; Grant sponsor: Beatriu de Pinós-A post-doctoral scholarship, Generalitat de Catalunya; Grant sponsor: European Union through Marie Curie Actions, FP7; Grant sponsor: Spanish Ministry of Science and Innovation; Grant number: CGL-BOS-2012-34717; Grant sponsors: Max Planck Society; Humboldt Postdoctoral Research Fellowship from the Alexander von Humboldt Foundation.

*Correspondence to: Dr. Luca Fiorenza, Earth Sciences, University of New England, Armidale NSW 2351 Australia.

E-mail: lfiorenz@une.edu.au

DOI: 10.1002/ajpa.22659

Published online 19 November 2014 in Wiley Online Library (wileyonlinelibrary.com). 


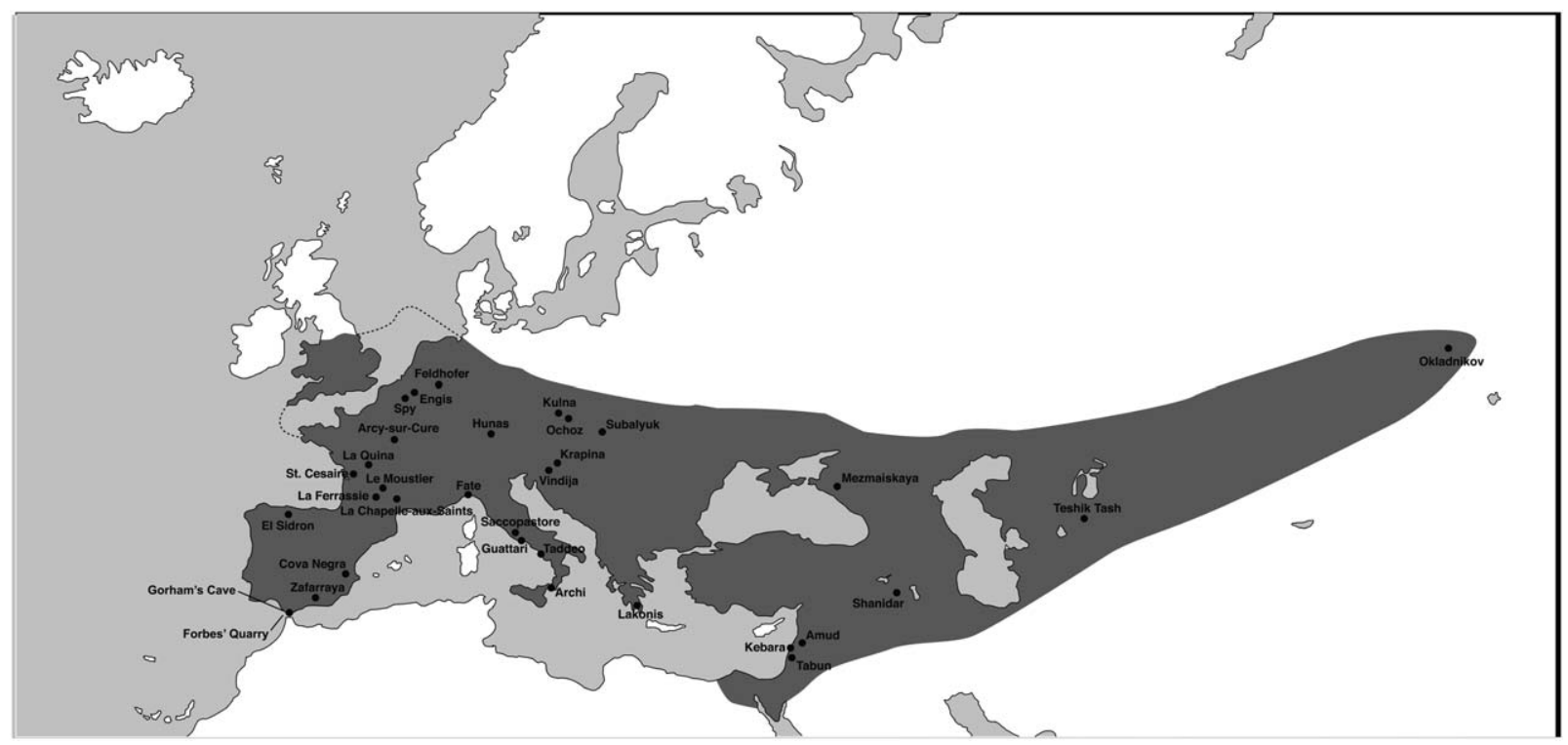

Fig. 1. Neanderthal geographic distribution from human fossil remains (Reproduced with permission from Krause et al., Nature, 2007, 449, 902-904).

1994; Holliday, 1997). Yet, a number of traits, such as the hyper-barrel-shape of the thorax, the thickened cortical bone and pronounced areas of muscle attachment, the length of the calcaneus and the large nasal piriform aperture, are thought to reflect extremely high levels of physical activity (e.g., Trinkaus, 1986; Franciscus and Churchill, 2002; Weinstein, 2008; Raichlen et al., 2011). Such activity patterns, together with the physiological stress induced by cold climates, would have imposed significant high-energy demands on Neanderthal bodies (Sorensen and Leonard, 2001; Steegmann et al., 2002; Churchill, 2006): metabolic requirements that would have forced Neanderthals to consume an energy-rich diet. Support for this argument mostly derived from stable isotopic analyses (e.g., Richards and Trinkaus, 2009), which suggested that Neanderthals obtained nearly all of their dietary proteins from animal sources, and occupied the higher level of the food trophic web, similar to the top-level carnivores of that time. The traditional interpretation of Neanderthals as exclusively meat-eaters, has, however, been challenged on several fronts over recent decades. Mounting evidence suggests that the nitrogen isotope record may underestimate the consumption of starch/carbohydrate rich plant foods by humans (Ambrose et al., 2003; Hedges and Reynard, 2007; Sponheimer and Lee-Thorp, 2007). More importantly, analyses of new archaeological evidence from the Mediterranean coastlines of Southern Europe and the Near East, dental wear studies, and microfossils in calculus, have demonstrated that Neanderthals were exploiting a wide variety of food sources (e.g. Stringer et al., 2008; El Zaatari et al., 2011; Fiorenza et al., 2011a; Henry et al., 2011; Salazar-García et al., 2013; Sistiaga et al., 2014). This unexpected dietary complexity, coupled with a very wide temporal and geographic range, has led many to reconsider the ecology and foraging strategies of Neanderthals.

To accomplish this task, here we review some traditional, as well as innovative approaches used in the reconstruction of Neanderthal diets, such as lithic and zooarchaeological analyses, stable isotopic methods, pale- opathology, tooth wear studies, and use of dental calculus. First, however, it is important to give a general introduction on Neanderthal geographic distribution, with a focus on climate and vegetation in Eurasia during the Middle and Late Pleistocene. It will be followed by a discussion wherein we summarize this information, taking into account ecological variation among Neanderthals and include nutrition and pathology-based arguments for a diet rich in animal proteins.

\section{NEANDERTHAL WORLD: GEOGRAPHIC DISTRIBUTION, CLIMATE AND VEGETATION}

Owing to the inexorable links between a habitat and its organisms (e.g., species of animals and plants), an assessment of Neanderthal subsistence patterns requires an overview of the environments in which they lived. Neanderthals occupied western Eurasia, a wide geographic area ranging West from the Iberian Peninsula East to Siberia (Krause et al., 2007), and North from Germany South to the Levant (e.g. McDermott et al., 1993; Wolpoff, 1996) (Fig. 1).

This region encompassed considerable topographical heterogeneity (e.g., interior and coastal areas, mountainous or relatively flat terrains), soil composition, and variation in temperature humidity, largely influenced by latitude. Besides that, Neanderthals are mostly documented from marine isotope stages (MIS) 6 through 3, a long period of time characterized by severe climatic conditions, with alternating glacial/interglacial cycles. This wide geographic distribution and climatic fluctuations during the Middle and Late Pleistocene drove the formation of diverse and discontinuous environments, spanning from warm and forested to cold and open habitats. Changing climate also strongly influenced the distribution patterns of mammalian herbivores and other food sources forcing Neanderthals to adapt to the new conditions.

The Mid-Late Pleistocene was marked by a general increase in aridification, but also great instability, with episodes of maximum ice expansion characterized by cold, dry conditions and sea levels drops of hundreds meters 


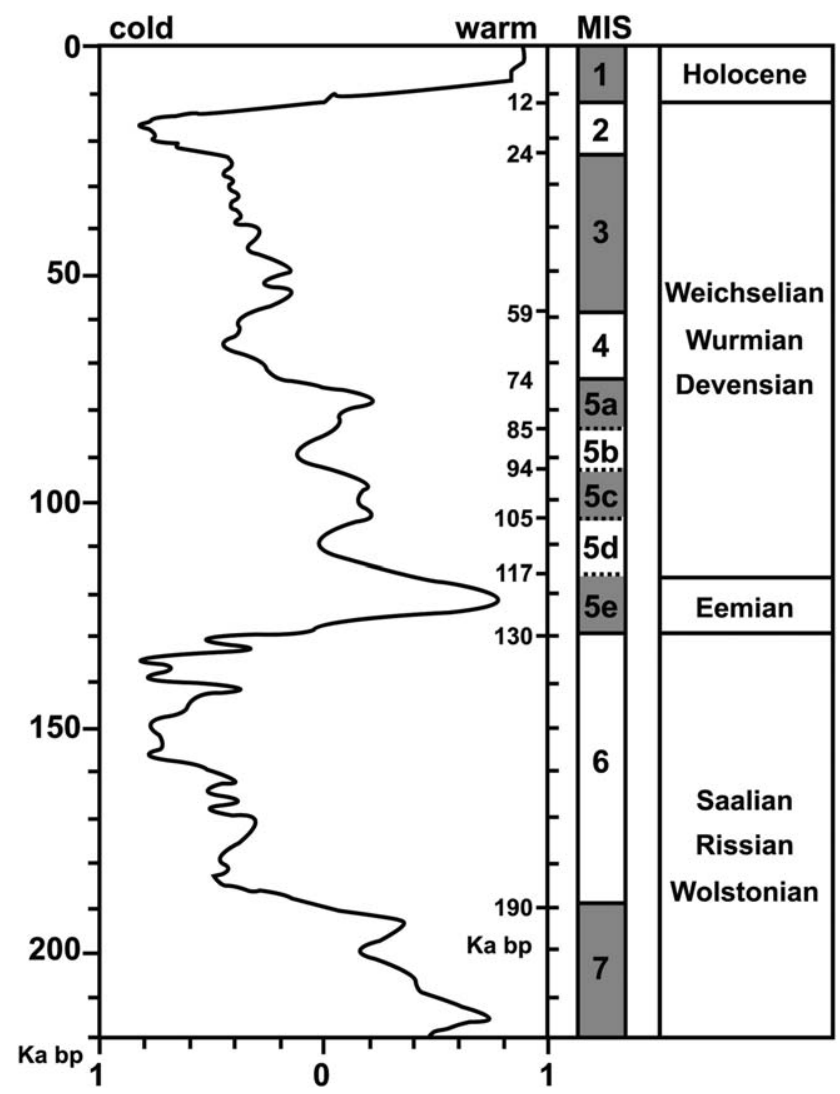

Fig. 2. SPECMAC (Orbital-based global chrono-stratigraphy) of the last 200,000 years, illustrating the climatic oscillations (warm intervals in gray) during the different Marine Isotopic Stages (MIS). Age in millennia (ka) (Reproduced with permission from Van Andel and Tzedakis, Quaternary Science Review 1996, 15, 481-500).

during glacial maxima, alternated by events of climate amelioration comparable to the present (interglacials). These "Ice Ages" culminated in the coolest and most variable period of the last glacial cycle (MIS 4-2, ca. 73.5-14.7 ka) (Harrison and Sanchez Goñi, 2010; Fig. 2).

The ice sheets formed during the penultimate glaciation (MIS 6, ca. 191-124 ka) reached their peak about $150 \mathrm{ka}$, and began to melt during the peak of the Last Interglacial (MIS 5e, ca. 123-110 ka; Bardají et al., 2009), with a volume even smaller than that of today (CAPE - Last Interglacial, Project Members, 2006). Climate gradually cooled during MIS 5d-a (ca. 109-73.5 ka) leading into the last glacial cycle (MIS 4-2). The first major ice advance at MIS 4 (ca. 73.5-59.4 ka) was followed by the highly fluctuating climate changes of MIS 3 (ca. 59.4-27.8 ka), with warm phases that in some cases approached Holocene temperature values, and cold phases similar to (but not as extreme as) the ones registered during the last glacial maximum (LGM) of MIS 2 (ca. 27.8-14.7 ka; Lisiecki and Raymo, 2005). Indeed, within the glacial/interglacial cycles, two types of abrupt millennial-scale climate oscillations of irregular periodicity (of too small duration or intensity to be considered either glacial or interglacial) have been recognized. The first type of climate oscillation, called DansgaardOeschger cycles (Dansgaard et al., 1984), was described in Greenland ice core records and is associated with rapid warming (Greenland Interstadial) and subsequent temperature cooling (Greenland Stadial; Svensson et al., 2006); a second type of rapid climate change is described in the North Atlantic as Heinrich events (HE; Heinrich, 1988), cold intervals associated with the formation of ice-rafted debris deposits (Elliot et al., 2001). Noticeably, the millennial-scale climate variability accounted for the Dansgaard-Oeschger and HE strongly affected the vegetation patterns at both the global and regional scales (Allen et al., 1999; Cacho et al., 1999; Wohlfarth et al., 2008; Wolff et al., 2010; Antoine et al., 2013): treedistribution changes modulated several factors, such as ice volume extent, amplitude of insolation, geographical position, and other local factors (Tzedakis, 2005).

During the climatic optimum of the Last Interglacial (MIS 5e), large regions of North Europe (such as the Fennoscandia, British Isles, Germany, Poland) were released by the melting of the thick ice-sheets formed in the Penultimate Glaciation. Seas rose to present day levels, and open forest of deciduous Quercus and Ulmus covered large parts of Europe, followed by coniferous evergreen trees (e.g., Picea, Pinus, Taxus) and deciduous trees (e.g., Corylus, Carpinus), with an expansion of Mediterranean evergreen woodland (e.g., Olea and evergreen oak) in southern Europe (van Andel and Tzedakis, 1996; Fig. 3).

The following MIS 5d-a is marked by several climate oscillations, causing an alternation between expanding open vegetation and forest conditions across Europe, and deciduous forests with Mediterranean taxa south of the Alps (Tzedakis, 1994).

During the onset of the last glacial cycle (MIS 4), icesheets advanced in North Europe (covering the Fennoscandia, Poland, Estonia and northwest Germany), but to a much lesser extent than in the LGM of MIS 2. In response to lower temperatures, northwestern, central, and eastern Europe landscapes above $50^{\circ} \mathrm{N}$ were largely treeless, dominated by tundra and cold steppe vegetation (Fletcher et al., 2010), with an abundance of grass (Poaceae), Artemisia, Chenopodiaceae, Pinus, and Juniperus (Allen et al., 1999; Fig. 4).

Arid cold steppe were documented also in southern Europe, although more temperate tree populations were generally maintained in southern refugia, such as the coastal regions of the Iberian Peninsula, Italy, the Balkans, Turkey, the Levant and probably Crimea (Finlayson, 2004). As mentioned above, the following MIS 3 was characterized by less severe glacial conditions (the ice cap covered only parts of the Fennoscandia), with sea levels ranging from -50 to $-80 \mathrm{~m}$, but with an increase in climate oscillations (Van Andel and Tzedakis, 1996). During interstadial periods northwestern and central Europe were covered by grassland and shrub tundra (e.g., Betula nana, Salix), while in northeastern Europe shrub- and forest-tundra dominated (Behre, 1989). Open boreal forest with Pinus, Betula, Larix, and Picea characterized Western Europe and the alpine region, while mixed coniferous and deciduous forest (e.g., Quercus, Corylus, and Fagus) covered southern Europe, with warmer temperate arboreal taxa at southerly locations (Fletcher et al., 2010; Fig. 5).

\section{TECHNOLOGICAL AND ZOOARCHAEOLOGICAL EVIDENCE}

Since the second half of the 20th century, rapidly improving zooarchaeological and taphonomic methods have been used to determine the relative importance of meat in the diets of Quaternary humans. These have allowed the assessment of the composition of preserved 


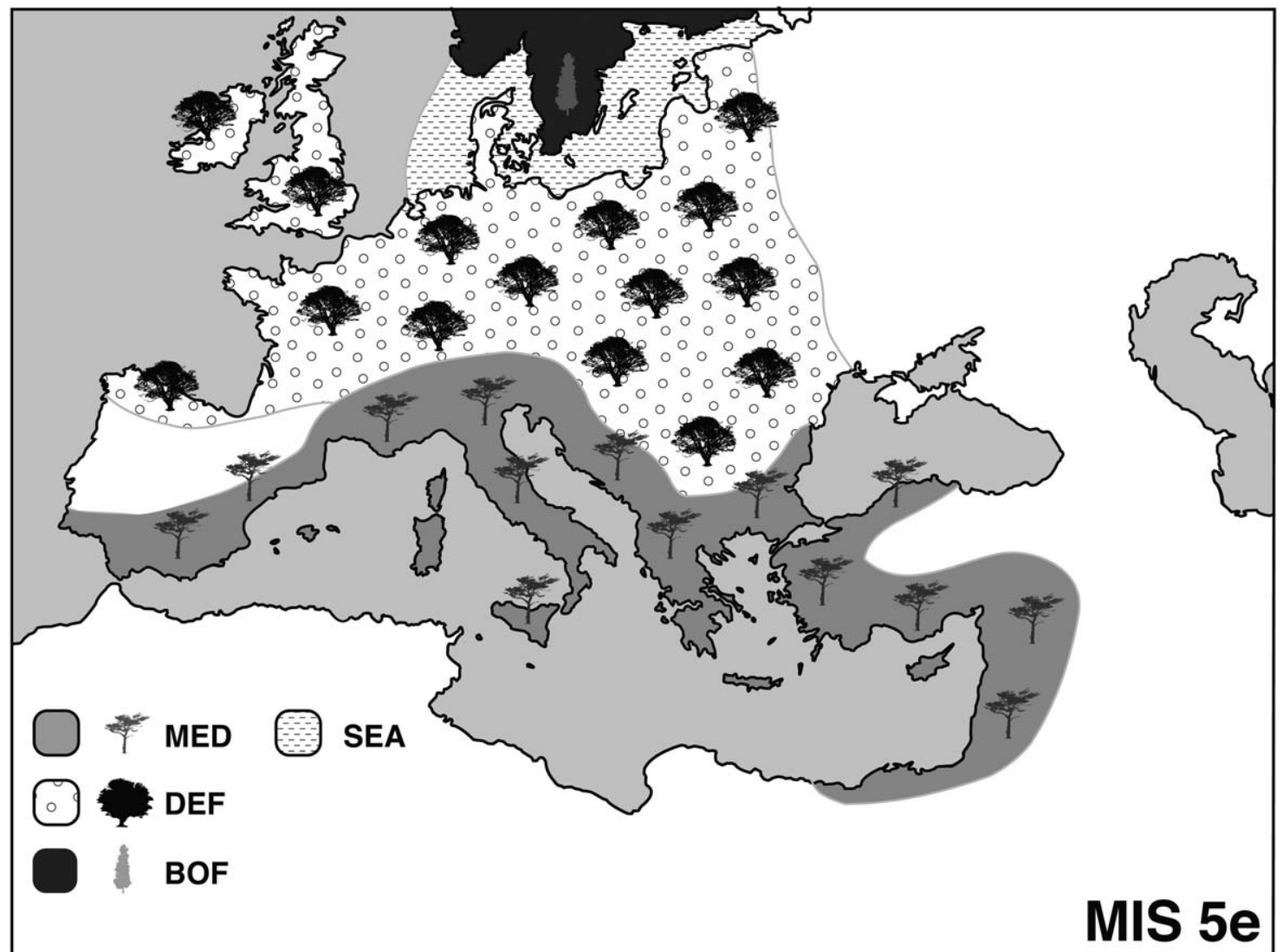

Fig. 3. Map of Europe during the optimum of the last interglacial (MIS 5e) at 120-125 ka (Reproduced with permission from Van Andel and Tzedakis, Quaternary Science Review 1996, 15, 481-500). Palaeoenvironments: boreal forest (BOF); deciduous forest (DEF); Mediterranean evergreen woodland (MED); Eemian/Baltic Sea (SEA).

faunal assemblages in sites from the direct evidence, that is, teeth and bones. Zooarchaeological approaches include the quantification of skeletal elements and their frequencies according to several measures, such as number of specimens, number of identified specimens, minimal number of element, minimal number of individuals, and minimal anatomic units, as well as the analyses of the structural and surface bone modifications (Lyman, 1994, 2008). The study of, mechanical and chemical, bone alterations provide data with which to reconstruct the taphonomic history of each specimen, allowing researchers to identify the main agents involved in the archaeological formation of the site, or bringing animals to the site. In the case of hominins, the activities related to the management of animal resources can be explored from cutmarks, diagnostic elements of an intentional bone breakage to access to marrow, and/or burned bones as evidence of roasting (e.g., Binford, 1981). Data from bone modifications in combination with the estimation indexes are used to infer the main steps in the procurement and butchery sequence, that is, method and type of acquisition (hunting types vs. scavenging), method of transporting the carcass, the processing and consumption techniques and the subsequent disposal of the remains. The resulting information can thus be corroborated with other archaeological aspects, specifically lithic tools, to make accurate predictions concerning the subsistence strategies and lifestyles of hominins for the period in question.

Since the earliest discoveries at the end of the XIX century, lithic industries have been examined with the aim of comprehending the function of the different stone tools and their relation to hunting and domestic activities. Earlier analyses were mostly focused on retouched tools with the compilation of typological lists based on strict relation between blank morphologies and presumed utilizations (Bordes, 1961; Heinzelin de Braucourt, 1962; Laplace, 1964). Although the broad consensus received, this approach was limited to a small portion of the lithic collections giving a reduced vision of the hominin technological organizations. In this way, new methodologies were developed to investigate the lithic productions and the use of lithic items in prehistoric societies: the technological and use-wear analyses. Technological analysis is accomplished using the concept of chaîne opératoire advanced by Leroi-Gourhan $(1943,1964)$ that enables the reconstruction of the various processes of flake production from the raw materials procurement, through the phases of manufacture and utilization until the final discard. Usewear analysis instead identifies the function of the lithic items through the recognition of wear traces, diagnostic fractures, and residues (Semenov, 1964; Hayden, 1979; Fischer et al., 1984). Technological analysis bases its interpretations on experimental knapping and replicative productions of retouched artifacts (Inizian et al., 1992; Boëda, 1994), whereas use-wear analysis originates with the correlation between the polish, or residues produced experimentally using different materials (wood, bone, antler, vegetal materials), and the archaeological evidence using optical or scanning electron microscopes (Semenov, 1964; Hayden, 1979). Technological and use-wear analyses 


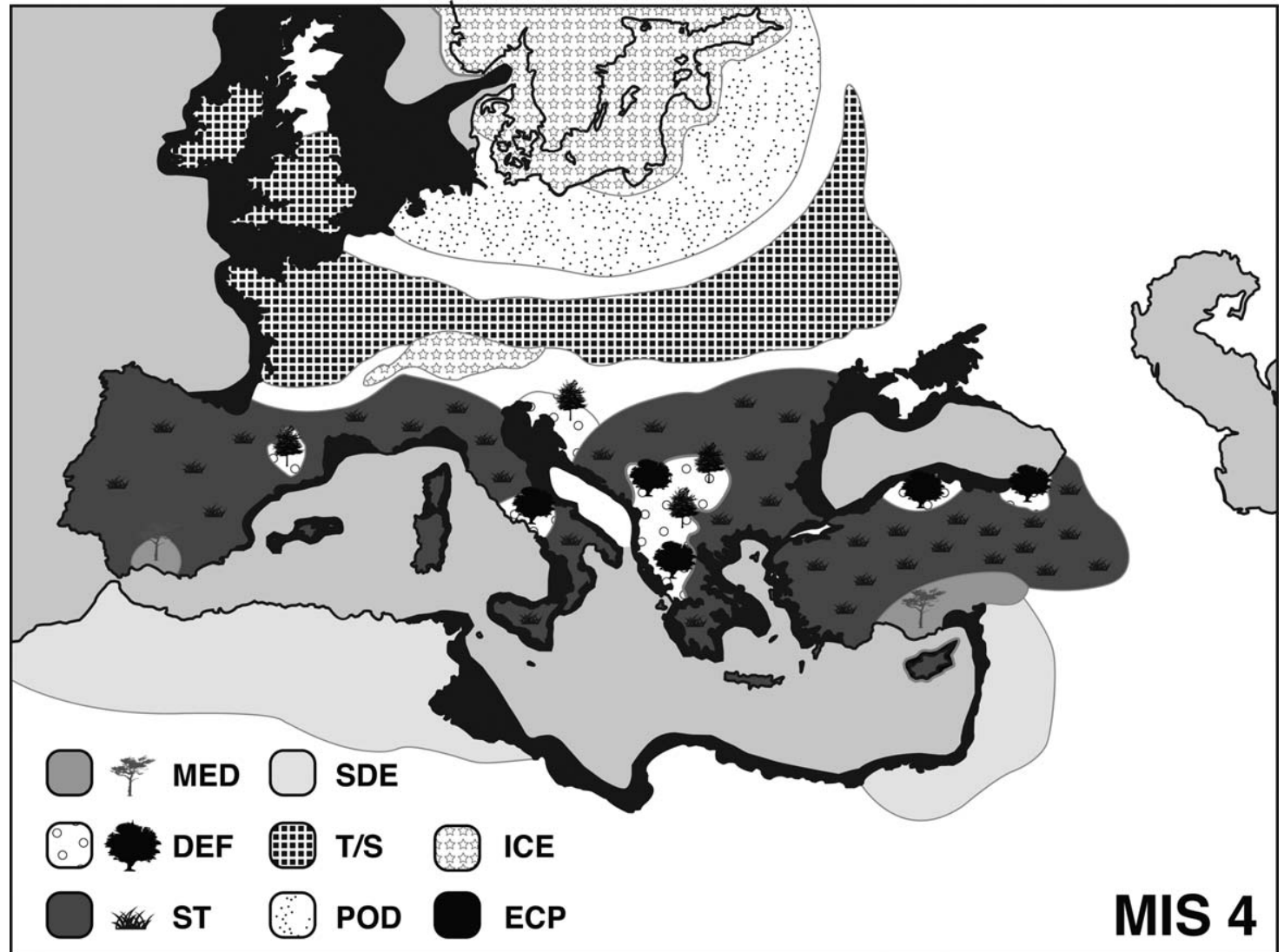

Fig. 4. Map of Europe at 65 ka (late MIS 4). Palaeoenvironments: ice-sheet (ICE); emerged coastal plains (ECP); polar desert (POD); tundra and cold steppe mosaic (T/S); arid cold steppe (ST); deciduous forest (DEF); Mediterranean evergreen woodland (MED); coniferous forest (CON); desert (DES) (Reproduced with permission from Van Andel and Tzedakis, Quaternary Science Review 1996, 15, 481-500).

are complimentary methodologies in the investigation of past human diets, integrating the evidence from the hunted prey animal with information about the toolkits manufacture and use (Calley and Grace, 1988).

As noted previously, Pleistocene Europe was subject to numerous and variable climatic oscillations that drove expansion and contraction of plant communities and the local appearance or extinction of animal species (Sirocko et al., 2007; Ehlers et al., 2011). Within the hypothesis of displacements towards southern territories, local extinctions may also have occurred at higher latitudes, followed by migration into northern areas during the climatic ameliorations from glacial refugia or other core areas (Hewitt, 2000; Hublin and Roebroeks, 2009; Von Koenigswald, 2011).

In the late Middle and Late Pleistocene, the human presence in Europe was more continuous with evidence of occupation also in areas at the fringes of the empty glacier territories (Condemi, 2006). The diet of European Neanderthals varied in this chronological interval on the base of the contraction and expansion in the mammalian communities driven by the climatic oscillations. During glacial stages the extension of the steppe/tundra environment in western-central Europe favored the dispersal of the "Mammuthus - Coelodonta" faunal complex from the arctic territories (Kahlke, 1999). The main mammalian components comprised woolly mammoth (Mammuthus primigenius), woolly rhinoceros (Coelodonta antiquitatis), Pleistocene arctic hare (Lepus arcticus), brown lemming (Lemmus sibiricus), reindeer (Rangifer tarandus), Pleis- tocene bison (Bison priscus), muskox (Ovibos moschatus), northern saiga (Saiga tatarica), wolf (Canis lupus), arctic fox (Alopex lagopus), polar bear (Ursus maritimus), and wolverine (Gulo gulo) (Ukraintseva, 2013). The Alps and the Pyrenees acted as natural barriers for some of these species in their displacements towards the Mediterranean territories (Kahlke, 1999). Saiga and muskox were absent in the Italian and Iberian Peninsula (Kahlke, 1992). Reindeer were common up to the Pyrenees and the Cantabrian fringe, whereas they were absent at southern latitudes of Spain, Italy, and Greece (Kahlke, 1999; Álvarez-Lao and García, 2011a; Gómez-Olivencia et al., 2013). Conversely, during the last glacial, little evidence of mammoth and woolly rhinoceros is recorded in southern-central Iberia (Álvarez-Lao and García, 2011a) and in the Italian peninsula (Palmarelli and Palombo, 1981; Palombo and Ferretti, 2005). The successive cooccurrence of these cold-adapted animals with more temperate faunal species highlights the existence in these regions of cryptic southern refugia where cold and arid environments persisted during interglacial conditions (Álvarez-Lao and García, 2011b).

During the climatic ameliorations of the interstadial periods the "Mammuthus - Coelodonta" faunal complex endured in western-central Europe, while the spread in northern latitudes of the "Elephas antiquus-Stephanorhinus kirchbergensis" faunal complex was favored only during the climatic shifts to a more maritime-influenced climate of the interglacial stages (Von Koenigswald, 2007). 


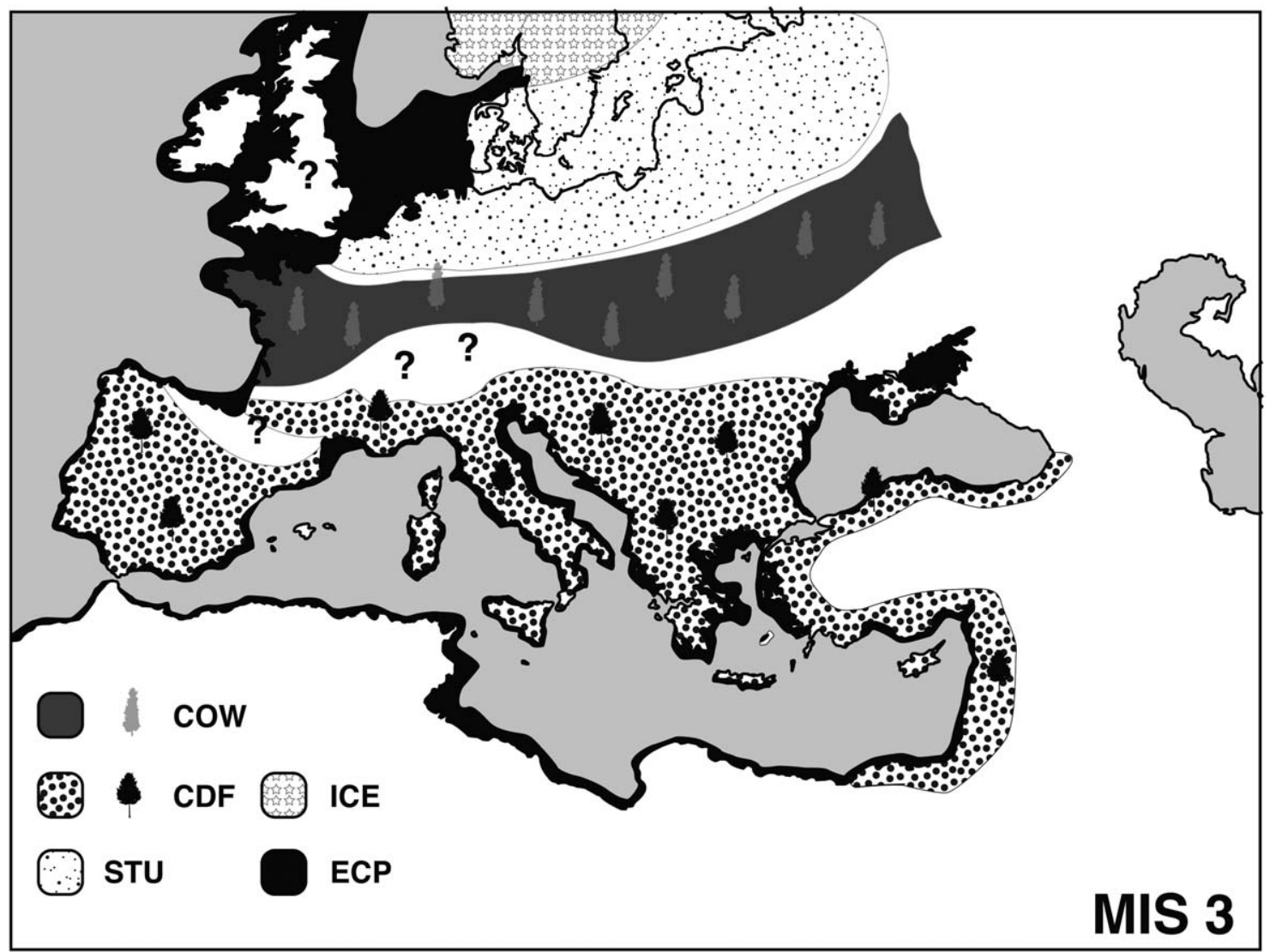

Fig. 5. Map of Europe during the warm phase of MIS 3 at 36-39 ka. Palaeoenvironments: ice-sheet (ICE); emerged coastal plains (ECP); shrub tundra (STU); conifer woodland (COW); mixed conifer and deciduous forest (CDF; Reproduced with permission from Van Andel and Tzedakis, Quaternary Science Review 1996, 15, 481-500).

This mammalian community was characterized by straight-tusked elephant (Elephas antiquus), Merck's rhinoceros (Stephanorhinus kirchbergensis), hippopotamus (Hippopotamus amphibious), auroch (Bos primigenius), roe deer (Capreolus capreolus), fallow deer (Dama dama), wild boar (Sus scrofa), and water buffalo (Bubalus murrensis) (Kahlke, 1999). The earliest evidence in central Europe of water buffalo, a species typical of subtropical Asian regions, is dated to MIS 7 at Steinheim II site (Germany; Von Koenigswald, 2011), whereas hippopotamus remains were recovered during MIS 5e from the sand deposits of the Rhine river (Von Koenigswald, 2007) up to the southern part of the British Isles (Schreve, 2001). Some other species showed higher environmental adaptability by recurring in faunal assemblages throughout the European territories, such as Irish elk (Megaloceros giganteus), horse (Equus sp.), red deer (Cervus elaphus), cave lion (Panthera spelaea), cave bear (Ursus spelaeus), and spotted-hyena (Crocuta crocuta; Von Koenigswald, 2011).

The archaeological evidence of Neanderthal subsistence strategies shows a great flexibility in foraging systems, with adaptations to different environments and variation across the faunal spectrum depending on species availability (Gaudzinski, 1995, 2006; Conard and Prindiville, 2000; Gaudzinski and Roebroeks, 2000; Costamagno et al., 2006; Discamps et al., 2011; Blasco and Fernández Peris, 2012b; Blasco et al., 2013). Indications of Neanderthals hunting activities are revealed by cut-marks, percussion marks, burned bones, and by the selection of prime-adults, a behavior contrasting with that of carnivores, which nor- mally target juveniles and older, weaker, individuals (Stiner, 2005). Furthermore the accumulation of faunal remains in archaeological sites shows a general tendency to transport the parts richest in flesh and marrow-limb bones (Stiner, 2005; Gaudzinski, 2006).

Another source of information of Neanderthals subsistence strategies is revealed by polish, striations and residues left on stone tools. The analyses of different Mousterian lithic assemblages disclosed evidences of butchering and animal processing (Rots, 2009; Hardy and Moncel, 2011; Vaquero et al., 2012; Hardy et al., 2013), whereas the study of residues demonstrated the processing of edible plants, mammals, fishes, and birds (Hardy and Moncel, 2011; Hardy et al., 2001, 2013).

Generally speaking, the core meat sources of Neanderthal diets were ungulates (Gaudzinski, 2006; Gaudzinski-Windheuser and Niven, 2009; Stiner, 2013). Although hunting practices focused on large-sized prey date as far back as the Early Pleistocene (DomínguezRodrigo and Pickering, 2003; Bermúdez de Castro et al., 2013; Huguet et al., 2013), an increase of archaeological sites documenting this phenomenon is noted at the end of MIS 9 in association with the introduction of Levallois technology (Scott and Ashton, 2011; Picin et al., 2013). This new knapping technology allowed higher numbers of flakes by core unit, thereby facilitating an increase in foraging radii and a reduced impact of raw material shortages, and greater spacing of resources. Earlier evidence of hunting weapons is limited to wooden spears at Schöningen (400 ka; Thieme, 1997), Clacton on Sea (350 
ka; Oakley et al., 1977), and at Lehringen (125 ka; Thieme and Veil, 1985), and to some bone damage, such as weapon impact notches on a horse scapula at Boxgrove $(400 \mathrm{ka})$ and on a cervid scapula at Swanscombe (Smith, 2012, 2013). Levallois technology enabled the production of thin and pointed flakes, occasionally retouched on both sides, with high penetrative capacities once hafted in wooden implements (Rots, 2013). Examples of their utilization in hunting activities are highlighted by the impact scars on some Levallois blanks at Biache-Saint-Vaast (Rots, 2013), La Cotte de Saint Brelade (Callow and Conford, 1986), Bouheben (Villa and Lenoir, 2009), and Oscurusciuto rock-shelter (Villa et al., 2009). The use of Levallois technology was not exclusive to the Middle Paleolithic: its coexistence with diverse flaking methods and lithic assemblages lacking the production of points, raises the issue of variable of toolkit by Neanderthals for big game (Picin, 2012).

During Middle Paleolithic times, Neanderthal subsistence tactics comprised long-term and seasonal exploitation strategies. Within cave and open-air sites, which were regularly used for the abundance of biotic resources, some hunting locations were selected to taking advantage of animal routes or seasonal migration, indicating anticipatory planning. In western-central Europe numerous archaeological sites are characterized by faunal assemblages in which one single species dominate (Gaudzinski, 2006). Large accumulations of bovids have been recovered at La Borde (MIS 7 or MIS 5; Jaubert et al., 1990), Coudoulous 1 layer 4 (MIS 6; Jaubert et al., 2005), Wallertheim layer B (MIS 5d; Gaudzinski, 1995), Mauran (MIS 3; Rendu et al., 2012), whereas bone assemblages dominated by reindeer were found at Salzgitter Lebenstedt (MIS 5-3; Gaudzinski and Roebroeks, 2000), Les Pradelles (MIS 4-3; Costamagno et al., 2006), and Jonzac level 22 (MIS 4; Jaubert et al., 2008). Long-term hunting strategies and recurrent settlements for the exploitation of bovids have been recovered at Biache-Saint-Vaast (MIS 7; Auguste, 1995). In some monospecific assemblages Neanderthals also targeted dangerous taxa such as Merck's rhinoceros at Taubach (MIS 5; Gaudzinski, 2006), Cave and Deninger's bears at Balve Cave (Kindler, 2007), and brown bears at Biache-Saint-Vaast (Auguste, 1995), woolly mammoths in layer 3 and woolly rhinoceros in layer 6 at La Cotte de Saint-Brelade (MIS 6; Callow and Conford, 1986). Although in the latter example, the hypothesis that these large herbivores were deliberately driven over a cliff requires more evidence.

The planned exploitation of particular species, using favorable landscape topography, such as cliffs, swamps or gorges to drive and entrap the herds, the use of specialized toolkits and the mortality patterns matching catastrophic episodes, provides evidence of collaboration and organization is some Neanderthal big game hunts (Rendu et al., 2008). All these aspects might be compatible with communal hunting and the possible subsistence strategy of addressing anticipated food needs through storing surplus meat.

Neanderthals from Mediterranean regions exploited large herbivores as well. However, the faunal spectrum was more varied and specialized hunting behaviors focused on particular species were absent, with the only exception of the red deer exploitation at Lazaret Cave (MIS 6; Valensi, 2000). Mousterian faunal assemblages of southern regions are commonly composed of cervids, bovids, and equids (Pérez Ripoll, 1977; Martínez Valle, 1996; Fiore et al., 2004; Valensi and Psathi, 2004; Brown et al., 2011; Blasco and Fernández Peris, 2012b; Dau- jeard et al., 2012; Rosell et al., 2012b; Salazar-García et al., 2013). The exploitation of dangerous taxa is evidenced by cut marks and processing activities on several species including straight-tusked elephants at Ambrona (MIS 9; Villa et al., 2005), Aridos 1 (MIS 9; Soto, 1980), Bolomor Cave layer XII (MIS 8; Blasco and Fernández Peris, 2012a) and Arriaga IIa (MIS 6; Rus and Vega Toscano, 1984); mammoths at Edar Culebro 1 (MIS 6/5; Yravedra et al., 2014) and Preresa (MIS 5; Yravedra et al., 2012); cave bears at Fate Cave (MIS 5) and Madonna dell' Arma (MIS 5) and brown bears at Manie Cave (Valensi and Psathi, 2004); lions in Gran Dolina TD10-1 (MIS 9) (Blasco et al., 2010); and Iberian dholes in Cova Negra (MIS 5d-b; Pérez Ripoll et al., 2010).

The diverse environmental and physiographical characteristics of the southern territories might have favored the exploitation of a wide range of food sources, with the integration of small prey (such as rabbits, hares, birds, tortoises; Stiner et al., 2000; Sanchis and Fernández Peris, 2008; Blasco and Peris, 2009; Blasco and Fernández Peris, 2012b; Cochard et al., 2012; Sanchis, 2012; Blasco et al., 2013; Salazar-García et al., 2013) and marine resources (such as shellfish and fish) (Brown et al., 2011; Colonese et al., 2011). These strategies that are still undocumented in northerncentral Europe (Gaudzinski-Windheuser and Kindler, 2012). In the south, in the Iberian and Italian Peninsulas the exploitation of marine resources were mostly restricted to the gathering of different shellfish species, while evidence for consumption of large marine fauna, such as monk seals (Monachus monachus), dolphins (Delphinus delphis, Tursiops truncatus), bluefin tuna (Thunnu sthynnus), and sea urchins (Paracentrotus lividus), is recorded so far only at Gibraltar (Stringer et al., 2008; Brown et al., 2011).

The integration of fast-small animals in the daily diet has been associated with the declining supply of high ranked animals, demographic growth, and technological developments (Stiner et al., 2000). However, the archaeological evidence during the Early and Middle Pleistocene indicates their possible importance in the evolution of hominin diet (Guennouni, 2001; Cochard, 2004; Costamagno and Laroulandie, 2004; Sanchis and Fernández Peris, 2008; Blasco et al., 2011; Blasco and Fernández Peris, 2012a; Sanchis, 2012; Blasco et al., 2013; SalazarGarcía et al., 2013). Some studies into nutritional ecology have challenged the hypothesis that small prey were marginal resources in human subsistence because of their lower net-energy return scale (Haws and Hockett, 2004), and they could have been ignored as long as high ranked resources were available (Kelly, 1995; Winterhalder and Smith, 2000). In fact, birds and rabbits could provide more kilocalories per hundred grams of flesh than the commonly hunted large herbivores and shellfish are particularly rich in vitamins D and E (Haws and Hockett, 2004). The lack of these specific elements in Neanderthal diets might have restricted the metabolic development of the individual (Haws and Hockett, 2005). However, the findings from some Mediterranean Basin sites -e.g., regular hominin consumption of rabbits, tortoises, and birds at Bolomor Cave (Blasco et al., 2013), shellfish and other marine animals in Gibraltar (Stringer et al., 2008), etc., point to the potential inclusion of these resources in the Neanderthal diets as regular alternative energy and vitamins sources, at least in more southerly southern latitudes.

During the Middle Paleolithic, hominin diets varied with climatic and environmental changes. They adapted their subsistence strategies to the new environs and shifts in mammalian distributions and abundances. Even 
though the feeding activities may look stable for the exploitation of a few animal species, the archaeology evidences quite generalist behaviors, with the utilization of local and seasonally available resources (Bar-Yosef, 2004). The hunting tactics were efficient with the successful targeting of large herbivores and dangerous species, including a large range of carnivores, such as cave lions, leopards, and cave and brown bears. On the whole the subsistence strategies were connected with technological innovations, mobility patterns, and domestic activities. However, analyses of the archaeological record are yet to provide information on the finer details of complex behavioral patterns that must have characterized the daily lives of archaic humans. The study of lithic and faunal assemblages reflects their practices only at broader scales. Future works crossing the zooarchaeological and lithic data, with the analysis of their refitting and spatial organizations at archaeological sites, are critical for the identification of temporal relations between the anthropogenic events and for a better understanding of the variability of foraging strategies of Paleolithic hunter-gatherers (Vaquero, 2008; Rosell et al., 2012a).

Finally, we have to take into account that other additional limitations exist, since the development of some activities or taphonomic processes may leave no detectable archaeological traces. In fact alkalinity in soil $\mathrm{pH}$ could increase the rate of bone mineral dissolution leading to its destruction (Linse, 1992). Weathering could also influence bone preservation, lowering its mineral content and progressively damaging its surface (Behrensmeyer, 1978). Under these taphonomic conditions, new-born/juvenile bones are more prone to be destroyed than those of mature individuals, yielding an incorrect picture of the performed hunting activities. Similarly, fishbone is unlikely to be preserved in the archaeological record because its chemical composition renders it far more susceptible to degradation (Szpak, 2011). Similarly, residues in lithic tools are sensitive to postdepositional processes, contaminations, and loss during excavations and laboratory activities (Grace, 1996; Langejans, 2011). The observation of strict protocols in collecting, cleaning, and compiling detailed maps of the residues on the analyzed tool are critical to eliminate contaminants and allow correct interpretations (Lombard and Wadley, 2007; Langejans, 2011).

In this panorama, the application of other complementary analytical techniques, such as stable isotopes, dental calculus and/or residue analyses, can contribute to more reliable assessments of hominin diet in an archaeological site, revealing activities and processes that are not visible on bones or stone tools.

\section{STABLE ISOTOPE ANALYSIS}

Isotopes are atoms of the same chemical element that have different numbers of neutrons (same atomic number, different mass number). They are considered "stable" if they are not subject to radioactive decay over time, in contrast to radiogenic isotopes. Analyses of the stable isotopes of carbon and nitrogen are commonly used to reconstruct past human and animal diets. This technique is based on the underlying rationale that the isotopic composition of food eaten is recorded on the body tissues after a predictable isotope fractionation (e.g., Katzenberg, 2000; Sealy, 2001; Lee-Thorp, 2008): in other words, "you are what you eat." Well preserved archaeological remains can retain the stable isotope ratios present during life, and therefore provide information about the foods an individual consumed. Stable isotope results are analyzed as the ratio of the heavier isotope to the lighter isotope ${ }^{13} \mathrm{C} /{ }^{12} \mathrm{C}$ and $\left.{ }^{15} \mathrm{~N} /{ }^{14} \mathrm{~N}\right)$ and expressed in " $\delta$ " notation in parts per mil $(\%)$, relative to internationally accepted standards (Schwarcz and Schoeninger, 1991).

Although many types of human tissues are suitable for stable isotope analysis, Neanderthal remains are exclusively represented by bones and teeth. These materials (with the exception of tooth enamel, which is a highly mineralized tissue) have both inorganic (ca. 75-80\% of dry weight) and organic matter (ca. 20-25\% of dry weight) (Hare, 1980). Most of the mineral part is hydroxyapatite (a calcium phosphate mineral), and around $90 \%$ of the organic matter is collagen protein. Each of these components have specific stable isotope ratios that reflect their chemical origin and formation: the inorganic fraction records carbon isotope ratios of the whole diet, while the organic part records carbon and nitrogen isotope ratios linked to protein consumption (Ambrose, 1990; Ambrose and Norr, 1993). Bone and dentine bulk collagen are the preferred substrate for carbon and nitrogen stable isotope analysis, in part because collagen is the only major nitrogen source from skeletal remains, and it provides robust quality indicators that securely record its isotopic integrity even from material older than 100 ka (De Niro, 1985; Bocherens et al., 1999; Van Klinken, 1999; Britton et al., 2011).

There are a few considerations to bear in mind when studying collagen isotope ratios. Collagen reflects the isotopic signals of the main dietary protein sources rather than those of the whole diet. This is especially true for the nitrogen signal, since almost all of the nitrogen in the collagen comes from dietary protein, while the carbon may be derived from other dietary macronutrients like sugars and fats (Howland et al., 2003; Jim et al., 2006). Because of slow collagen turnover, stable isotope values from adult human bone collagen represent an averaged protein diet over a number of years prior to death (Ambrose, 1990; Schwarcz and Schoeninger, 1991; Hedges et al., 2007). In contrast, collagen from dentine does not undergo remodeling and thus reflects only the diet of the specific period during tooth formation (manly childhood). Furthermore, isotope values from dentine and bones of young individuals could be influenced by breastfeeding and weaning (Fuller et al., 2006; Eerkens et al., 2011), and thus providing information not comparable to values from adult bones.

Sampling Neanderthal remains is complicated, since many times one cannot choose and instead is obliged to analyze any available material (bone or dentine). One of the most commonly used methods for collagen extraction (Richards and Hedges, 1999) is shown on Figure 6. After extraction, collagen is usually analyzed in an Isotope Ratio Mass Spectrometer coupled with an Elemental Analyzer to produce $\delta^{13} \mathrm{C}$ and $\delta^{15} \mathrm{~N}$ isotopic values. The $\delta^{13} \mathrm{C}$ stable isotope ratio distinguishes the consumption of terrestrial and marine foods (Chisholm et al., 1982; Peterson and Fry, 1987). It can also be used to determine the relative dietary proportions from $\mathrm{C}_{3}$ and $\mathrm{C}_{4}$ plants (all trees, shrubs and herbs, as well as temperate or shade-adapted grasses are $\mathrm{C}_{3}$ plants, while $\mathrm{C}_{4}$ plants are mainly tropical grasses) or animals that consumed them (Van der Merwe and Vogel, 1978; O'Leary, 1981). However, because there are no known $\mathrm{C}_{4}$ plants in Europe during the Late Pleistocene (Cerling, 1999; Sage et al., 1999), $\delta^{13} \mathrm{C}$ values in Neanderthals are primarily used to distinguish between marine and terrestrial $\mathrm{C}_{3}$ protein consumption. However, the interpretation of $\delta^{13} \mathrm{C}$ values becomes more complicated if brackish water fish is integrated in the diet 

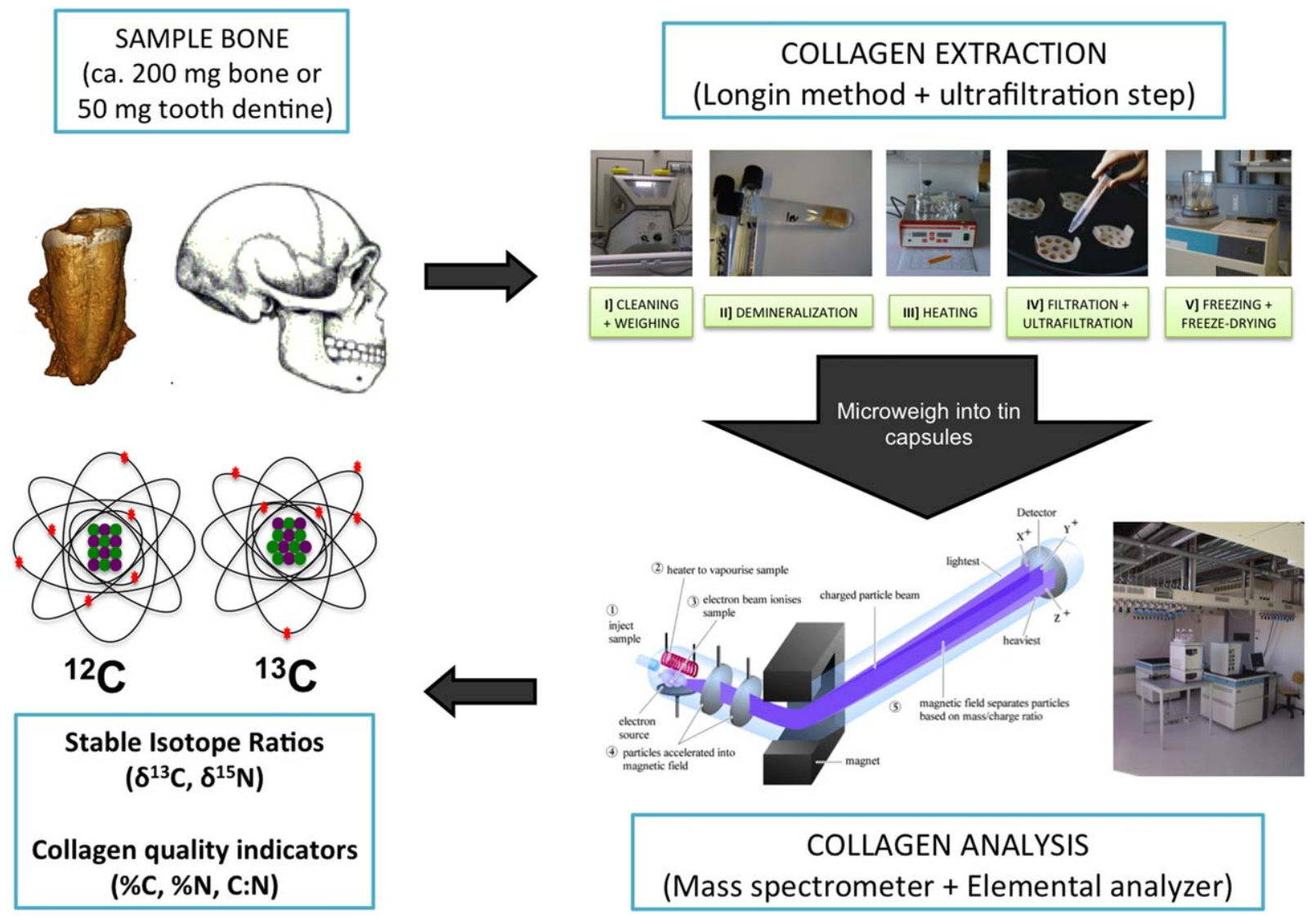

Fig. 6. Schematic representation of sampling, extraction, and collagen analysis for carbon and nitrogen stable isotope analysis. Collagen extraction follows the Longin Method (Longin, 1971) with an addition of an ultrafiltration step (Brown et al., 1988). [Color figure can be viewed in the online issue, which is available at wileyonlinelibrary.com.]

(Salazar-García et al., 2014a). The $\delta^{15} \mathrm{~N}$ stable isotope ratio increases by 3-5\% per trophic level in the food chain (Bocherens and Drucker, 2003), and is usually used to indicate the position in the food chain (De Niro and Epstein, 1981; Minagawa and Wada, 1984; Sponheimer et al., 2003). Aquatic food chains tend to contain more trophic levels than terrestrial ones: thus, individuals having a marine or freshwater-rich diet, will have higher $\delta^{15} \mathrm{~N}$ stable isotope values than individuals consuming mainly terrestrial food products (Schoeninger et al., 1983; Schoeninger and De Niro, 1984). Theoretically, omnivore $\delta^{15} \mathrm{~N}$ values would then fall between herbivore and carnivore values. Based on the exact values of the nitrogen ratio, it is potentially possible to determine whether omnivores obtained their protein mainly from plants, animals, or a mix of both (low values of $\delta^{15} \mathrm{~N}$ mean a larger proportion of plant foods, while high values would mean increased meat consumption). However, this quantification is less straightforward than previously thought since large changes in protein sources may be indicated by only small changes in $\delta^{15} \mathrm{~N}$ values (Hedges and Reynard, 2007; O'Connell et al., 2012), and the determination can be further complicated by special cases in which plants have higher $\delta^{15} \mathrm{~N}$ values than expected (e.g., Warinner et al., 2013). A further issue to take into consideration is that $\delta^{15} \mathrm{~N}$ values can be influenced by different environmental settings through time (see review in Pearson, 2007). For all these reasons, nitrogen isotope ratio values for a hominin should be compared to faunal samples, ideally from the same archaeological site and level. This would ensure the detection of differences in the nitrogen environment baseline, avoiding thus to incorrectly attribute them to dietary reasons (Bocherens et al., 2014). Accordingly, $\delta^{15} \mathrm{~N}$ values are still appropriate to differentiate between individual that consumed more animal resources (carnivores and omnivores) from those who consumed very little animal proteins (vegetarians and vegans; Bol and Pflieger, 2002; Petzke et al., 2005; Fahy et al., 2013).

\section{Neanderthal dietary isotopic evidence}

During the last two decades stable isotope analyses on Neanderthal specimens, and associated fauna from 120 to $30 \mathrm{ka}$, have contributed to a better understanding of their diets. The first analyses on Neanderthal's collagen isotopic ratios were done on individuals from Les Pradelles (France) in the early 1990s (Bocherens et al., 1991; Fizet et al., 1995). Because collagen is not preserved well in warmer climates, most of these analyses have been focused on Neanderthals that lived during cold climatic cycles and at high latitudes, including: Scladina Cave (Bocherens et al., 1999, 2001), Awirs Cave (Bocherens et al., 2001) and Spy Cave (Bocherens et al., 2001) in Belgium; Vindija Cave (Smith et al., 1999; Richards et al., 2000; Higham et al., 2006) in Croatia; Saint-Césaire (Bocherens et al., 2005), Rochers de Vileneuve (Beauval et al., 2006), Jonzac (Richards et al., 2008b) and new specimens from Les Pradelles (Bocherens et al., 2005) in France; Kleine Feldhoffer Grotte (Richards and Schmitz, 2008) in Germany; in 
Netherlands (Hublin and Roebroeks, 2009); and Okladnikov (Krause et al., 2007) in Russian Siberia.

Independent analyses of these specimens show a quite uniform Neanderthal diet, regardless of geographic area and chronology (for more details, see previous reviews by Lee-Thorp and Sponheimer, 2006; Bocherens, 2009; Richards and Trinkaus, 2009). Neanderthals always fall at the highest level of the food chain when compared with same site associate fauna (e.g., Richards et al., 2000, 2008b; Bocherens et al., 2005) or to contemporary Eurasian fauna (e.g., Iacumin et al., 2000; Richards and Hedges, 2003). This suggests that they were top predators that obtained almost all of their dietary proteins from terrestrial animal resources (mainly medium and large-sized herbivores). Neanderthals show much higher nitrogen values than do herbivores (such as reindeer, red deer, horses, Spanish ibex, chamois, steppe bison, or aurochs), and are similar in this respect to apex predators (such as wolves, hyenas, and lions). This high intake of animal proteins is usually interpreted as indicative of high activity levels among Neanderthals; sophisticated hunters who spent much of their time pursuing game (Richards, 2002; Richards and Schmitz, 2008). The consistency of this pattern suggests that high-meat diet was a rigid dietary model exclusive to Neanderthals, which in turn could have made they vulnerable if competed for food resources with modern humans (Fabre et al., 2011).

In recent years, this isotope-based interpretation has been challenged. First, some have argued that the use of a small sample size and lack of specimens from warmer time periods or more southern latitudes, cannot accurately describe the entirety of Neanderthal dietary breadth (Hardy, 2010). Previous attempts to extract collagen from Neanderthals from warmer periods and regions with different environments were not successful (e.g., Ambrose, 1990). However, new carbon and nitrogen stable isotope studies on bone collagen from southern European Neanderthal specimens are beginning to address this gap. Four Neanderthal remains and associated fauna from Middle Paleolithic sites in the central area of the Mediterranean coast of Iberia (Cova Negra and Abric del Salt) have provided the first isotopic evidence of Neanderthal diet from southern latitudes and temperate regions, broadening the range of their dietary geographical picture. These Neanderthals have similar isotope values to those living in colder environments, and indicate a diet that is based largely on terrestrial foods, such as the different-sized herbivores found at the sites (SalazarGarcía et al., 2013). These results suggest that Neanderthals living in latitudes with milder climatic conditions and presumably more abundant plant foods also consumed a diet consisting of large amounts of animal proteins.

A second general criticism of early isotopic works on Neanderthal diets was that isotope-based analysis on bulk collagen represents only the protein contribution to the diet, and therefore should not be used alone in portraying Neanderthal dietary patterns (e.g., Hardy, 2010). It has been recognized that even moderate quantities of meat (high density of proteins) in the diet could mask significant plant consumption (overall with a low protein density), since the quantity of plant versus meat reflected in the $\delta^{15} \mathrm{~N}$ is nonlinear (Bocherens, 2009). Some calculations suggest that the difference in $\delta^{15} \mathrm{~N}$ values between a $100 \%$ meat diet and a diet with a 50:50 meat to plant ratio would be roughly $0.5 \%$, making it difficult to distinguish the proportion of meat consumed over that threshold (Bocherens, 2009). However, when using stable isotope analysis, individuals with diets that are based on plant foods should still be recognizably different from those that consumed a significant amount of meat, in cases where there is associated fauna for comparison. Even with these considerations in mind, there have been to date no Neanderthals with isotope values that indicate a diet based predominantly on plant foods. This should not be interpreted to mean that they did not consume plants when they were available, however.

A third criticism is that many of the Neanderthal samples analyzed by isotopes have no associated fauna or come from juvenile individuals or dentine, and thus should not be considered to portray Neanderthal dietary patterns (Bocherens, 2009). While this is definitely an issue when interpreting the proportion of meat and plant proteins consumed, it cannot be apply to aquatic resources, and thus should not invalidate the use of isotopic signatures for dietary reconstructions in these circumstances. Carbon and nitrogen stable isotope analyses are still able to clearly detect regular marine protein input into the diet (Richards et al., 2003). Moreover, Neanderthal adult specimens that have no associated fauna can still be used as a valid proxy for the consumption of marine resources. In a similar way, data from Neanderthal juvenile specimens and dentine, which may be influenced by a breastfeeding residue signal (significant increase in $\delta^{15} \mathrm{~N}$, slight increase in $\delta^{13} \mathrm{C}$ ) and thus not able to situate the individual on the trophic chain, are still useful to detect marine resource intake by them or their mothers (higher $\delta^{13} \mathrm{C}$ is expected). Furthermore, analyzing dentine collagen is important when trying to detect marine protein consumption, since by giving information on a narrower time window (specific childhood periods) it can record smaller input of marine resources that would be undetected in bone collagen (which averages several years prior to death).

Because freshwater foods have a very wide isotopic value range, which may overlap with other type of resources, freshwater protein consumption cannot be clearly detected using carbon and nitrogen stable isotope analyses. To date there is no Neanderthal isotopic evidence of freshwater resource consumption. New techniques, such as sulphur stable isotope analysis on bulk collagen (Nehlich et al., 2010) or carbon and nitrogen stable isotope analysis on amino acids (Smith et al., 2009; Naito et al., 2013), may provide better information about the consumption of various aquatic foods by Neanderthals.

\section{PLANT MICROREMAINS}

Previous studies of Neanderthal diets have focused on the apparent homogeneity among Neanderthal groups and their focus on large game, and underestimated the importance of other food sources. Information about plant foods in particular is lacking, in large part because plant remains generally do not survive well in archaeological contexts. Plant foods would have likely been valued components of Neanderthal diets. Energy-rich plants were available even in cold glacial environments (Hardy, 2010), and some studies have suggested that Neanderthals did use these foods. Macrobotanical remains in the forms of charred seeds have been found in the Mousterian levels of Kebara in Israel (Lev et al., 2005) and Gorham's Cave in Gibraltar (Barton et al., 1999). Phytoliths from edible plants have been recovered from sediments in several Near Eastern Neanderthal sites (Henry et al., 1996, 2004; Albert et al., 1999, 2000; Madella et al., 2002; Rosen, 2003). More direct evidence for Neanderthal use of plants comes from studies of residues on stone tools (Hardy, 2004; Hardy and Moncel, 2011; Hardy 
a) Phytoliths

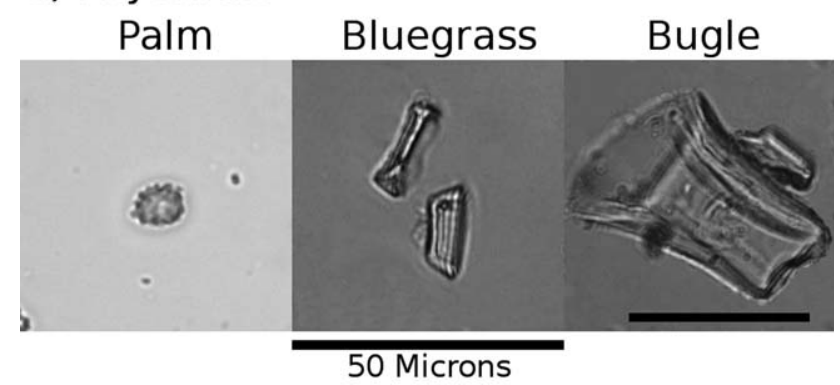

b) Starches Wheat

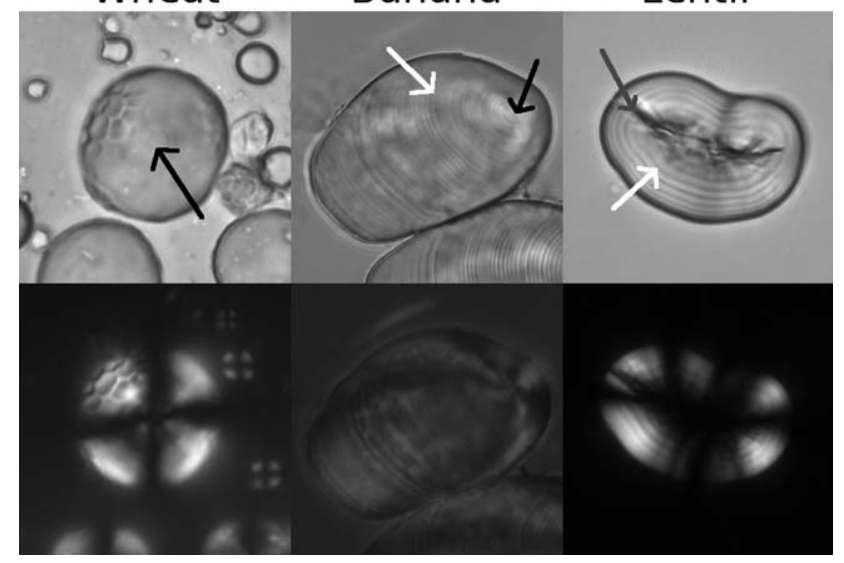

Fig. 7. Phytoliths and starch grains from a variety of plant species. In (b), black arrows indicate the hilum, white arrows indicate lamellae, and the gray arrow indicates a diagnostic crack.

et al., 2001, 2013) and dental calculus (Hardy et al., 2012). These studies provide the first tantalizing view of plant use by Neanderthals, but are limited in their application, either providing only indirect evidence of plant use (e.g., phytoliths and seeds in sediments) or giving limited or no information about which exact species were consumed (tool and calculus residue analysis).

In contrast to these methods, plant microremains preserved on stone tools and in dental calculus provide the most direct record of plant use, and in some cases can identify the exact plant species that was consumed. Plant microremains are microscopic remnants of plants that preserve taxon-specific morphology. The two plant microremains used for dietary analysis are phytoliths and starch grains.

The word "phytolith" comes from the Greek words for "plant rock." Phytoliths are formed when plants concentrate soluble silica from the groundwater and deposit it in a solid, noncrystalline form within and between their cells (Pearsall, 2000; Piperno, 2006). Phytoliths provide structural support for plant tissues, and may be a defense against herbivory, since they can remodel tooth enamel and may function as mimics of dust particles (Massey and Hartley, 2006; Massey et al., 2007a, b; Lucas et al., 2013). They are formed primarily in the above-ground organs of plants such as leaves, husks, rinds, bark, fruits; a few taxa accumulate them in their subterranean structures. When the plant dies, these siliceous bodies are left behind and are only rarely affected by taphonomic processes, such as dispersal by wind or fire; they are, however, highly soluble under conditions of high pH (Piperno, 2006; Fraysse et al., 2009). Phytoliths take on unique morphologies depending on the plant taxa and plant part in which they formed. In some cases, phytolith morphology is unique to an individual species (Rapp and Mulholland, 1992; Piperno, 2006). Commonly, the morphology is diagnostic of a higher taxonomic level, such as genus, tribe, sub-family or family. Phytoliths can have morphologies that vary between and within plants by size, shape, texture and ornamentation, and anatomical origin (Madella et al., 2005; Piperno, 2006; Fig. 7a).

Starch grains are formed in plants as a means of energy storage. There are two main types, transitory starch and reserve starch. Transitory starches form within the green parts of plants during the day and are transformed into sugars at night (Badenhuizen, 1969; Cortella and Pochettino, 1994; Preiss, 2009). They are usually small and with few diagnostic features (Haslam, 2004; Shannon et al., 2009), and are of limited use in microremains studies. Reserve starches form within various plant parts, particularly those areas where long-term energy storage is needed, like the seeds, fruits, and underground storage organs (USOs; Sivak and Preiss, 1998; Preiss, 2009). Reserve starches are generally larger than transitory ones, and have more diagnostic potential. Starches are made up of two kinds of glucose chains, amylose and amylopectin, which form radial chains that branch out from the central formation point, called the hilum. The growth of the starch is characterized by alternating rings of amorphous and more crystalline layers, called lamellae. Although chains of amylose and amylopectin run through both crystalline and amorphous lamellae, it is generally thought that the more organized branching pattern of amylopectin is responsible for the crystalline lamellae and that amylose is concentrated in the amorphous ones (Blanshard, 1987). This alternating crystalline and amorphous structure gives starch grains many of their unique features, including their resiliency under certain environmental conditions, their weakness in others, and their distinctive interference cross when viewed under cross-polarized light. Starches, like phytoliths, can be preserved for long periods in protected environments, especially on the surfaces of tools, in food residues found in pottery, and in dental calculus (Loy et al., 1992; Piperno et al., 2004). There are several taphonomic conditions that commonly and quickly remove starches from archaeological sediments, including low $\mathrm{pH}$ and exposure to soil-borne enzymes (Haslam, 2004). Starch grains are known to have characteristic morphology that allows researchers to identify the plant family, tribe, genus and, in some cases, the species that produced them (Reichert, 1913, 1919; Seidemann, 1966; Piperno and Holst, 1998; Piperno et al., 2000; Torrence et al., 2004; Torrence and Barton, 2006). Starch grains vary in size, shape, position and appearance of the hilum, lamellae, fissures, other types of surface decorations, and interference cross (Fig. 7b).

The durable nature and diagnostic morphologies of starch grains and phytoliths makes them an ideal tool for studying Neanderthal diets. When found trapped in the dental calculus on teeth, they can provide information about the plants that individuals and groups consumed. Dental calculus is the mineralized plaque that forms on teeth. Saliva is supersaturated in calcium phosphate to prevent the dissolution of the enamel during the consumption of acidic foods and to counter the destructive nature of some oral bacteria. Bacteria form pellicles, or skins, over the surface of the teeth, and this roughened skin becomes a site for precipitation of the calcium phosphate. Bacteria then grow again over the mineral layer, and the process repeats, forming a layered plaque that can range from scant microns to several millimeters thick. The plaque is 
increasingly mineralized over the lifetime of the individual, eventually forming a thick calculus deposit that preserves bacteria, oral proteins, and food remains in a dense mineral context (Warinner et al., 2014; Power et al., 2014; Salazar-García et al., 2014b).

To extract dietary information, the calculus deposit is processed to release the plant microremains, examined under a microscope, and the microremains are identified by comparing their unique characteristics to a reference collection of modern plants.

There are several limitations with plant microremains analysis in general, and with studies of dental calculus in particular. First and foremost, not all plants produce starches or phytoliths, so these plants will be invisible in the microremain record. Second, there is a level of redundancy in the microremain records, so that certain microremain types are seen in several different plant species. Similarly, some plants produce several different kinds of microremain types, so there is not a one-to-one relationship between microremain types and plant taxa. Furthermore, there are several formation and taphonomic processes that can remove starches and phytoliths from the archaeological record (Henry, in press; Pearsall, in press). Contamination from modern sources can also be an issue, so extreme care must be taken to properly curate, clean, and sample archaeological materials (Henry, in press). In addition, not all plants that are introduced into the mouth were eaten as food; some may be processed in the mouth (e.g., basket reeds, twine for hafting, etc.), while others may be ingested as medicine or recreation. Finally, the formation of dental calculus varies considerably among individuals due in part to genetics, diet, and disease, so that different amounts of time may be represented by the calculus deposit. Some groups may naturally form more calculus at a faster rate than others, so that they are more likely to trap food remains. This may cause disparities when comparing between groups. However, once these potential issues are addressed, it is possible to recover information about the consumption of particular plants and to achieve a partial understanding of the number of different plants consumed by a group.

Plant microremains from Neanderthal dental calculus have indicated a broad use of plant foods in a variety of environments. In Europe, the calculi from the Spy individuals had a large number of starch grains, a third of which were from a single species, a USO of the Nympheae (waterlily) family (Henry et al., 2011). Other European Neanderthals, including Arcy-sur-Cure, Goyet, Kůlna, La Chapelle-auxSaints, La Ferrassie, La Quina, Malarnaud, and Sima de las Palomas had fewer plant microremains in their calculus, but overall there were several starches consistent with those from seeds from grasses in the Triticeae (relatives of wheat and barley) and in the Andropogoneae or Paniceae tribes (Salazar-García et al., 2013; Henry et al., 2014), as well as starches belonging to a variety of other plants. In the Near East, Neanderthals from Shanidar Cave also consumed grass seeds from the Triticeae tribe (Henry et al., 2011), several of which were likely to have been cooked. In addition, their calculus preserved phytoliths from date palms (Phoenix spp.), and starches from several other plant species. Most European samples had about five different types of plant microremains (each of which may represent one or more different plant species); in contrast, the samples from Spy and those from Shanidar each had almost 50 different microremain types preserved in their calculus (Henry et al., 2014). There are no consistent differences in terms of identified plants or number of microremain types among individu- als from central Europe (Kůlna), western Europe (Belgian and French sites), southwestern Europe (Sima de las Palomas), and the Near East (Shanidar) though this may be due to the very small sample sizes outside of western Europe.

Combined with the results from previous studies, the analysis of plant microremains recovered from dental calculus indicates that a variety of starch-rich plant foods, particularly from grass seeds and USOs were consumed by Neanderthals across Europe and the Near East. Future studies that include more individuals from outside of western Europe will allow us to determine if there are dietary differences at a finer eco-geographic scale.

\section{TOOTH WEAR}

Dental wear is a dynamic and natural process resulting in a gradual loss of the tooth surface. It records information about physical properties of the food eaten, food processing and cultural habits of an individual. The removal of the enamel layer begins with food ingestion and mastication and is caused by three main mechanisms: attrition, abrasion, and erosion (Kaifu et al., 2003; Addy and Shellis, 2006; Kaidonis, 2008). Attrition is a mechanical wear produced by the contact between opposing teeth. The attritional contacts between the occlusal surfaces of upper and lower teeth create flat and polished areas with welldefined borders called wear facets (Hillson, 2003). Abrasion is a physical wear caused by the friction of exogenous material forced over the tooth surface (Kaifu et al., 2003; Kaidonis, 2008). Abrasion does not produce characteristic macroscopical features, but the action of abrasive particles can generate particular microwear patterns formed by "scratches" and "pits" (Kaidonis, 2008). Abrasive wear in hunter-gatherer societies was mostly caused by the intake of hard and fibrous foods, and by incidental introduction of foreign materials with food, as dust and grit from their environments (Addy and Shellis, 2006). In contrast, erosion is the loss of tooth surface due to chemical dissolution induced by intrinsic (regurgitated gastric acids) and extrinsic (soft drinks, pickles and acidic fruits) acids (Addy and Shellis, 2006; Ganss, 2006). Erosion generally produces cup-shaped dentine wear, leaving rough surfaces with etched enamel prisms. The mechanisms of attrition, abrasion and erosion act together, each with a varying intensity and duration to produce a multitude of different wear patterns (Ganss, 2006; Kaidonis, 2008). However, the prevalence of erosion among huntergatherer and prehistoric populations seems insignificant (Kaidonis, 2008), and the major cause of tooth wear in these groups appears to be a combination of attritional and abrasive mechanisms (Kaifu et al., 2003).

Tooth wear has largely been used for dietary reconstruction of past human populations, and it can be studied at two different scales: macrowear (visible to the naked eye or at low magnification) and microwear (visible only under microscope). Here, we review how dental macro- and microwear have been used to reconstruct the diet of Neanderthals.

\section{Dental macrowear}

Early works on Neanderthal dentition initially focused on the heavy anterior tooth wear. On the basis of the distribution of macroscopic wear facets, Heim (1974) concluded that Neanderthal tooth wear was a consequence of the consumption of a rough vegetable diet. In the following year, Wallace (1975) found similarities between 
the frontal teeth of La Ferrassie 1 and Bushmen, suggesting that the rounded incisors were probably the result of abrasion by dietary grit. However, most scholars disagreed with this hypothesis, and related this type of incisor wear to a habitual use of the teeth as tools, for cutting, holding and shaping a variety of objects (e.g., Brace, 1967; Bermúdez de Castro et al., 1988; Lalueza Fox and Frayer, 1997). Skinner (1997) analyzed the wear rates in deciduous anterior teeth of Neanderthals and anatomically modern humans (AMH) from the Upper Paleolithic, discovering an earlier onset of wear in the AMH sample. He associated deciduous tooth wear with the introduction of solid foods, suggesting that Neanderthal infants weaned at later ages than AMH.

Other studies qualitatively observed and described the occlusal wear in Neanderthal's posterior teeth. Trinkaus (1983) associated the advanced degree of wear of the Neanderthals from Shanidar with the consumption of abrasive food and with the presence of a dusty environment. Smith (1984) looked at the flatness of molar wear as indicator of food toughness, by comparing hunter-gatherer and early agriculturist populations. She also used a Paleolithic sample including a few Neanderthal specimens from Tabun, La Ferrassie, La Quina, and Gibraltar. Her results showed that with the introduction of more sophisticated food preparation methods, which caused a significant reduction in food toughness, molar wear patterns became increasingly more oblique. The intake of a tough and fibrous diet would have produced flatter wear. The Paleolithic sample stands out from the early agriculturalist and modern huntergatherer groups showing the flattest wear of all. This would suggest a highly abrasive diet, but due to an insufficient sample size, it was not possible to statistically confirm this interpretation (Smith, 1984).

All these early works on Neanderthal dental macrowear suggest the consumption of a highly abrasive diet, but do not provide any further information of what type of food was actually eaten. With advances in computer technology and with a better understanding of the relationship between mastication and occlusal contact areas (Douglas and De Vreugd, 1997), Kullmer et al. (2009) developed a novel approach (Occlusal Fingerprint Analysis, OFA) that uses $3 \mathrm{D}$ digital surface models of teeth to analyze wear facet patterns and determine their structural parameters: facet area, perimeter, inclination and orientation. Major occlusal movements and sequential tooth-to-tooth contacts between upper and lower teeth can be drawn in a three-dimensional space from individual occlusal compasses. The information encoded in the occlusal compass can be used to show how contact areas are created and what movements are responsible for their formation. Comparative studies of the relationships between jaw movements, occlusal wear and the physical properties of food in extant non-human primates (e.g., Kay and Hiiemae, 1974; Janis, 1990), were fundamental for the interpretation of dietary habits of fossil species in which tooth-to-tooth occlusion occurs (Ulhaas et al., 2007; Kullmer et al., 2009; Fiorenza et al., 2011b; Fig. 8).

The OFA method has been applied to the analysis of dental macrowear in 19 Neanderthal (Krapina, Tabun, Monsempron, Shanidar, Amud, Vindija, and Le Moustier) and 12 AMH (Qafzeh, Mladeč, Barma Grande, Sungir, and Pataud) specimens (Fiorenza et al., 2011b). These two Pleistocene hominins have been grouped into three wide eco-geographic contexts, derived from paleoenvironmental information, geographic distribution, and chronological data. The macrowear patterns in these two species indicate large geographic dietary variation independent of taxonomic affinities. Thus, Neanderthals and modern humans who lived in comparable environments likely consumed similar food sources. Comparisons with recent hunter-gatherers with known dietary habits have suggested a restricted diet, rich in meat, in Neanderthals from cold areas (Monsempron, Vindija and Le Moustier), and the intake of highly diverse food sources, including plant foods, in Neanderthals from Mediterranean (Tabun, Shanidar and Amud) and deciduous woodland (Krapina) habitats. In another study, Harvati et al. (2013) analyzed the dental macrowear of the Neanderthal remains from Kalamakia Cave (Southern Greece), indicating a diet similar to those Pleistocene humans from mixed habitats, with the intake of animal and plant foods. Finally, a recent study of Neanderthals from Central Italy revealed the use of diverse food sources with a prevalence of meat in the specimens from Saccopastore, and a diet composed of animal and plant foods in the specimens from Guattari's cave, with an increase in meat consumption at later MIS (Fiorenza, 2015).

Because Neanderthals and modern humans are characterized by morphological differences in their posterior teeth (Bailey, 2002, 2004; Bailey et al., 2014; GómezRobles et al., 2007; Benazzi et al., 2011a, b, 2012, 2014a, 2014 b), one may reasonably presume that wear facets in these two species reflects dental morphology. However, the relationship between molar wear pattern and tooth morphology has been quantitatively tested, and no significant correlations has been found (Fiorenza et al., 2011c). This further demonstrates that tooth macrowear patterns in Neanderthals and modern humans are mostly determined by ecological conditions.

\section{Dental microwear}

Pioneering works on dental microscopic features initially focused on heavily worn Neanderthal teeth from La Ferrassie. Puech (1981) examined the density and orientation of enamel grooves (microscopic depressions on the tooth surface) of anterior and posterior teeth, finding similarities with masticatory behaviors of Australian Aborigines. He suggested that Neanderthals from La Ferrassie relied on a highly abrasive diet composed of meat and vegetables. $\mathrm{He}$ also hypothesized that the increase in abrasiveness could have been caused by the use of earth ovens and food desiccation methods, which can incorporate exogenous materials such as dust and sand. However, by comparing micrographs of the anterior teeth of La Ferrassie 1 and 2 with those of gorillas, Inuit and other Western European Neanderthals, Brace et al. (1981) offered another explanation that suggests that Neanderthal anterior dental microwear was the consequence of use of teeth as tools.

For this reason, most anthropologists subsequently avoided the use of the anterior dentition to obtain information about diets in prehistoric human populations, and started to focus on microwear patterns of buccal and occlusal surfaces of posterior teeth. Lalueza Fox and Pérez-Pérez (1993) initially studied the striation (or scratch) pattern of the Neanderthal child from Devil's Tower (Gibraltar 2). They looked at the buccal surfaces of deciduous molars, assuming that vestibular striation patterns in human populations are not affected by short-term seasonal dietary changes. They considered three main variables: number, length, and orientation of striations. A high number of striations corresponded to an increase of 

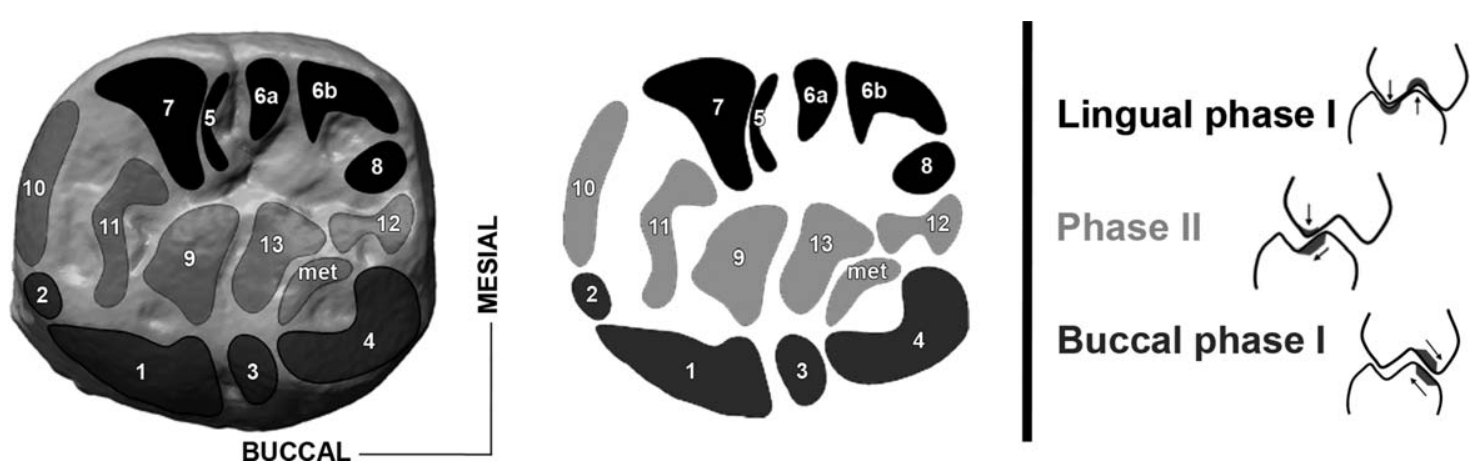

Fig. 8. Digital 3D model of Neanderthal second lower molar (Guattari 2, Italy) showing wear facets and masticatory processes occuring during the chewing phases (lingual phase I facets, phase II facets and buccal phase I facets) Neanderthal second lower. Wear facets have been labeled following the numbering system created by Maier and Schneck (1981) and grouped by chewing cycle phases (Kay and Hiiemae, 1974; Janis, 1990). Orientation: lingual (L) and distal (D).

abrasiveness in the diet, while the ratio between vertical and horizontal striations depended on dietary habits.

For example, while the buccal wear pattern in populations consuming high proportions of meat is characterized by fewer striations and a relatively high proportion of vertical ones, those of hunter-gatherers that rely on a more vegetarian diet display an increased number of striations, with a greater proportion of horizontal ones (Lalueza Fox and Pérez-Pérez, 1993; Pérez-Pérez et al., 1994; Lalueza et al., 1996; Fig. 9). The analysis of the microwear features of Gibraltar 2 revealed a pattern dominated by a high number of vertical striations: this suggested a mostly carnivorous diet, similar to those of Inuit and Fuegians, but with a higher contribution of abrasive particles (Lalueza Fox and Pérez-Pérez, 1993). In another study, Lalueza et al. (1996) analyzed the buccal microwear of different modern huntergatherer, pastoralist, and agriculturalist populations. The microwear patterns of these modern groups were then compared with those of Middle and Upper Paleolithic humans. The authors found that some of the Neanderthal specimens examined in this study (Tabun 1 and 2, La Quina 5 and Amud 1) had a microwear pattern similar to that of more carnivorous modern hunter-gatherers, while the Neanderthals from St. Cesaire, Marillac, and Malarnaud resembled that of mixed-diet hunter-gatherers. The relatively large microwear pattern variability found in the Neanderthal group became more evident when the same scientific team analyzed a larger Middle Paleolithic sample (Pérez-Pérez et al., 2003). In this study, these authors analyzed 21 Neanderthal specimens (Tabun, Amud, La Quina, Gibraltar, Malarnaud, Saint Césaire, Marillac, El Salt, Hortus, and Macassarques) observing a high intragroup variation in the number of striations, which was inconsistent with the idea of a homogenous and strictly carnivorous diet. The hetereogeneity of the Neanderthal buccal microwear pattern indicates the exploitation of a wide range of foods, including abrasive vegetable materials. When Pérez-Pérez et al. (2011b) attempted to correlate buccal microwear density with the climatic conditions prevailing in Europe during Late Pleistocene, they discovered a significant increase in microwear features during cold MIS, while warmer periods corresponded to a reduction of scratch density. This seems to be related to a shift in Neanderthal dietary strategies during cold phases, where a diet rich in meat was supplemented with abrasive plant foods such as bulbs and roots.

In recent years, occlusal microwear texture analysis has been widely used for the reconstruction of diets in fossil species (Ungar et al., 2003). This new methodology is a combination of confocal microscopy and scale-sensitive fractal analysis, and considers microwear variables, such as surface complexity, anisotropy, heterogeneity, and texture fill volume (Scott et al., 2006). By analyzing the microwear patterns of various modern hunter-gatherer groups, El Zaatari (2010) found that surface complexity was the most useful variable in discriminating their dietary habits (Fig. 10A,B). For example, the intake of a highly abrasive diet, which can be caused by the ingestion of hard vegetable materials or by the use of diverse food preparation techniques (such as freezing and desiccation processes), will result in more complex surfaces. However, a diet that is predominantly based on meat will correspond to anisotropic surfaces, since the mastication of meat (which is a tough but not hard food item) would have required repetitive directional jaw movements (El Zaatari, 2010; Fig. 10C,D). Occlusal microwear texture analysis was firstly used to detect dietary information in the Neanderthal child from Trou de l'Abîme at Couvin (Belgium; Toussaint et al., 2010). The microwear features of the deciduous molar examined in this study suggests a diet mostly consisting of tough items, with few brittle foods, typical of a largely carnivorous diet. Subsequently El Zaatari et al. (2011) used a larger sample size $(N=25)$, discovering that although the microwear signatures of Neanderthal teeth are consistent with a diet rich in meat, it also suggests that plant foods formed an important part of their diet. In particular, it was shown that Neanderthal microwear patterns follow paleoecological conditions. Because the examined Neanderthal sample consists of specimens that are well-spaced chronologically and from a wide geographical range, El Zaatari et al. (2011) divided this group into three diverse paleocological categories, finding a correlation between tree cover expansion and increase of surface complexity and

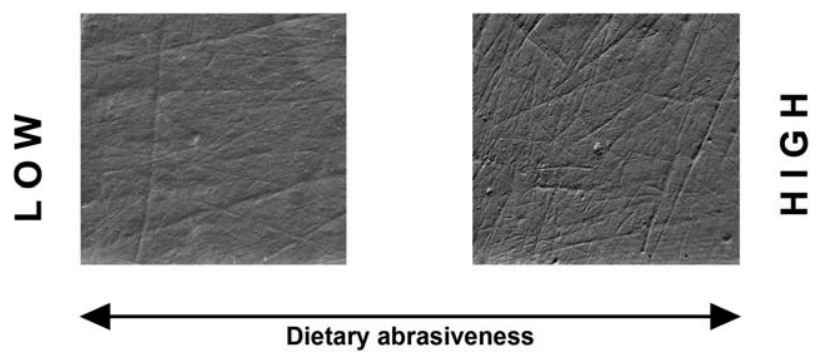

Fig. 9. Buccal microwear patterns related to physical properties of food (after Romero et al., 2013). 

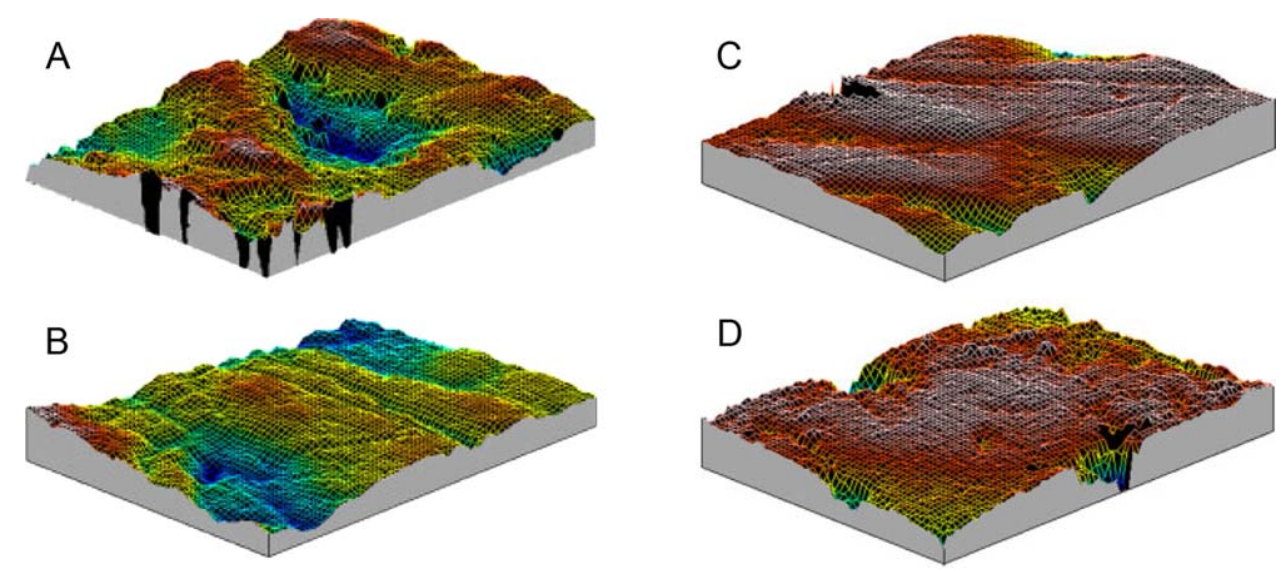

\section{Surface complexity}

\section{Anisotropy}

Fig. 10. Three-dimensional axiomatic representations showing tooth surfaces with relatively high (A) and low (B) complexity, and with relatively high (C) and low (D) anisotropy (after El Zaatari, 2010). [Color figure can be viewed in the online issue, which is available at wileyonlinelibrary.com.]

heterogeneity, which indicate the consumption of hard items and a growth in individual dietary variability. Thus, the Neanderthals from wooded habitats (Zaffaraya 1, Grotta Breuil 2, El Sidrón 1, and Amud 1) probably had access to a wide range of food sources, consuming higher proportions of plant foods.

The comparisons with modern hunter-gatherers with known diets show a close similarity between the Neanderthals who inhabited cold-steppe environments (Spy 1, Subalyuk 1, Grotte de l'Hyène IVb6 B9, La Quina 5, and 20) and Fuegians, suggesting a diet mostly consisting of meat. In contrast, the Neanderthals who lived in areas with mixed vegetation group together with the Chumash, indicating a diet that incorporated several plant foods as well meat. Moreover, because paleoecological data were unavailable, these authors analyzed the Neanderthal specimens of Ochoz 1, Guattari 3, Saccopastore 1 and 2, Monsempron 3 and Tabun 1, separately. While Ochoz 1 and Guattari 3 cluster with the Neanderthals from open environments, the two specimens of Saccopastore and Tabun 1 group together with the Neanderthals from wooded habitats. Finally, the microwear pattern of Monsempron 3 differs from all other Neanderthals examined and closely resemble that of Khoe-San from the Kalahari Desert, suggesting a mostly vegetarian diet. Hlusko et al. (2013) analyzed the microwear patterns of Neanderthal teeth from Moula-Guercy (France), showing a close similarity with the wooded habitats group, and therefore suggesting a diet mostly composed by meat but with the intake of other types of food, including vegetables. Furthermore, the microwear results of two recent studies place the Neanderthals from Lakonis and Kalamakia (two localities of Southern Greece that are $30 \mathrm{~km}$ away from each other) into two slightly different dietary categories (mixed diet for Kalamakia, and more carnivorous diet for Lakonis), which reflect the chronology and paleoecology of these sites (Harvati et al., 2013; El Zaatari et al., in press).

\section{Methodological limitations}

Dental wear studies are now recognized as demonstrably valuable tools in the determination of diet in prehistoric human populations. They have permitted analyses of larger Neanderthal samples, revealing dietary complexity and variation, which was previously undetected by more traditional methods. However, both macrowear and microwear have limitations. It is well understood that interpretations based on microwear alone can be problematic because of the "last supper" effect (Grine, 1986). Microwear features can change abruptly, yielding information only about an individual's diet in the weeks or even days before its death, and therefore may not offer insight into their long-term diets (Wood and Schroer, 2012). This is especially problematic for groups with seasonally variable diets. This may be overcome by using larger sample sizes (Scott et al., 2012). Yet, because many factors can influence the development and occurence of tooth wear, it can be difficult to either determine the major cause of wear or to evaluate how different wear mechanisms have interacted (Addy and Shellis, 2006). This is particularly true when dealing with human populations that introduce large amounts of abrasive agents in their diets due to the adoption of various food processing methods, or use their teeth as tools for daily task activities. Thus, such cultural habits may mask the effective relationship between food and macrowear and microwear features, leading to incorrect interpretations. Fortunately, paramasticatory uses of teeth generally produce distinctive types of wear which can readily be related to specific tool functions (e.g., Molnar, 1972; Fiorenza et al., 2011a; Fiorenza and Kullmer, 2013; Fiorenza, 2015). However, this does not solve the problem with wear patterns that are greatly influenced by food preparation techniques. As observed by Pérez-Pérez et al. (2003) and El Zaatari et al. (2011), modern models of microwear might not be representative of past populations' diets. They both suggest that caution must be applied when comparing recent hunter-gatherers to Pleistocene humans, particularly when using modern carnivorous populations (such as Inuit and Fuegians) as analogs for Neanderthals.

In the future, new tooth wear studies may consider how the enamel surface responds to different masticatory forces and to different food items. Nanowear experiments based on hardness testing are at the forefront here, and will likely have profound implications for dietary reconstructions in past human populations (Lucas et al., 2013). Moreover, because dental wear is a dynamic process, longitudinal studies are necessary if we want to better understand how wear patterns change and evolve through time. 

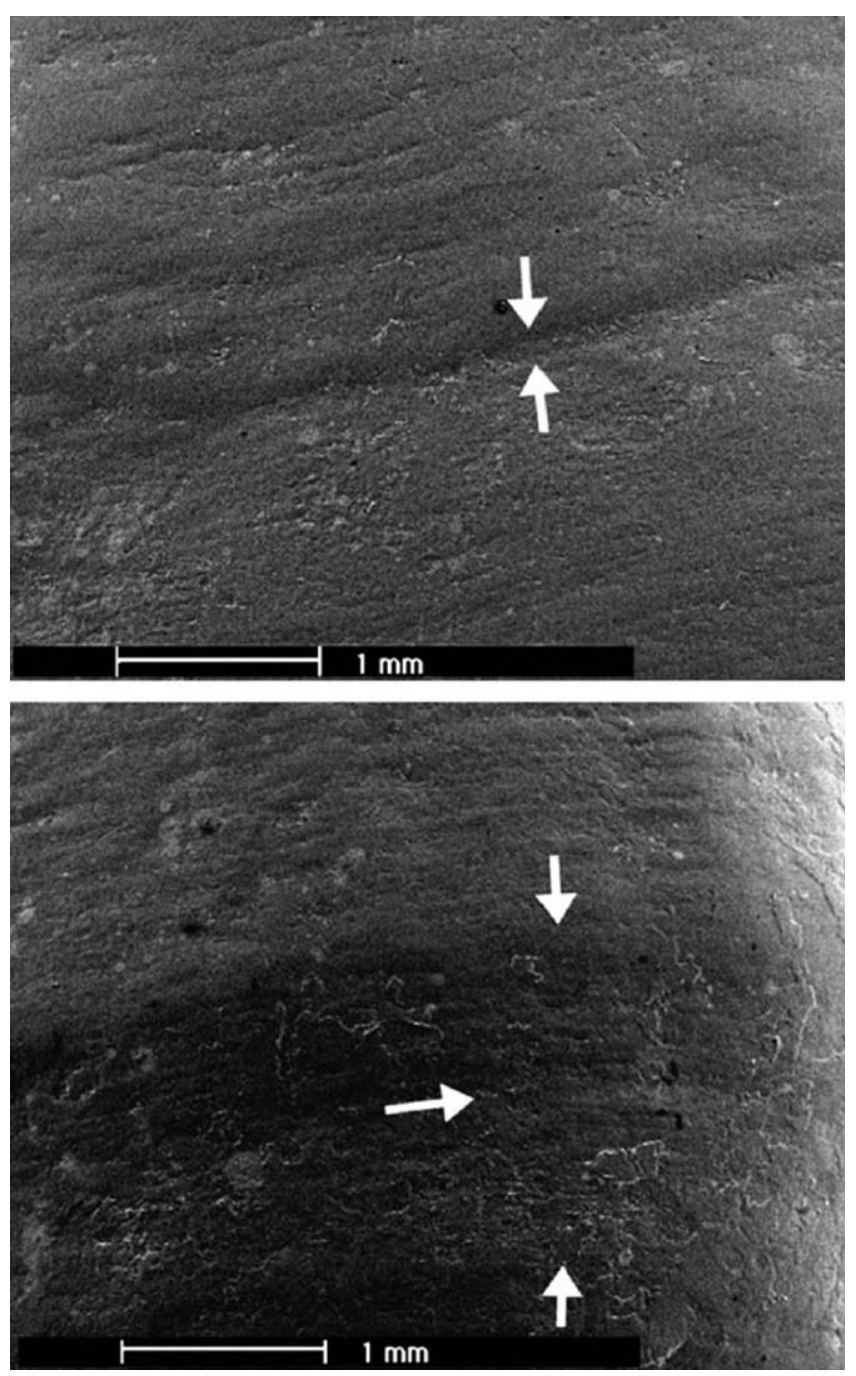

Fig. 11. Two linear enamel hypoplasia defects on Neanderthal tooth surface from Krapina (after Guatelli-Steinberg et al., 2004).

\section{DENTAL PATHOLOGIES AND SKELETAL TRAUMAS}

Paleopathology, the study of ancient diseases, is an important tool to identify and quantify health in past human populations. Age-at-death estimations, recognitions of physical trauma patterns and analyses of stress indicators such as dental enamel hypoplasia, are some of the paleopathology-based methods employed to reconstruct demographic trends, lifestyle, and nutrition in Neanderthal populations. For example, Trinkaus (1995) considered the mortality distribution in European and Near Eastern Neanderthals, revealing a low life expectancy and a high mortality pattern in young adult individuals. Similarly, Soffer (1994) found a relatively higher degree of infant mortality compared to AMH. These demographic patterns, together with the high incidence and distribution of traumatic lesions, all indicate highly stressful lives (Berger and Trinkaus, 1995; Pettitt, 2000). This latter "Rodeo Riders" hypothesis has been reconsidered by Trinkaus (2012), who abandoned the idea of inefficient hunting weaponry, suggesting that patterns of trauma seen in
Neanderthals were probably associated with multiple causes, including interhuman violence (Estabrook, 2009).

In a similar manner, the study of dental pathologies demonstrates periodic episodes of physiological stress during growth and development in Neanderthal children. Enamel hypoplasia is a developmental defect caused by the disruption of ameloblasts during the formation of enamel matrix (Hutchinson et al., 1997; GuatelliSteinberg et al., 2004; Fig. 11). Genetic anomalies and environmental factors, such as infectious diseases and malnutrition, are responsible for the interruption of ameloblast proliferation (Ogilvie et al., 1989). Because genetic disorders and infectious diseases were extremely rare in prehistoric human populations, the high frequencies of enamel hypoplasia characterizing the Neanderthal group has been associated with nutritional stress (GuatelliSteinberg et al., 2004). In particular, Molnar and Molnar (1985) and Ogilvie et al. (1989) observed the formation of enamel hypoplasia in the majority of individuals from the Krapina site, suggesting that this Neanderthal group was under sever stress due to nutritional deficiencies.

Additionally, Hutchinson et al. (1997) analyzed the Neanderthals from Krapina considering another type of enamel defect: hypocalcification. This dental pathology is caused by the alteration of the mineralization of the enamel matrix, and as enamel hypoplasia, it is correlated with stressful life events during childhood (Hutchinson et al., 1997). Because high frequency of enamel hypoplasia corresponded with increased levels of hypocalcification, these authors suggested that these two types of enamel deficiencies represent parallel metabolic stress episodes, probably related to malnutrition and unstable environments.

The large prevalence of enamel disruptions in Neanderthal teeth has led to interpretations that associate nutritional stress with a lower foraging efficiency and with unpredictability in Neanderthal diets (Ready, 2010). Similarly, Hockett and Haws (2005) used this paleopathological evidence and data from faunal analysis and stable isotopes to formulate a new hypothesis on Neanderthal nutritional ecology. According to these two authors, Neanderthals had a narrow undiversified diet, lacking in essential micronutrients such as vitamins $\mathrm{A}, \mathrm{B}, \mathrm{C}$, and $\mathrm{E}$, which would have led to an increase in maternal and fetus-to-infant mortality. While some modern human groups, such as the Arctic Inuit, showed no signs of micronutrient deficiencies despite a diet composed almost entirely of meat and fish (e.g., Wei Wo and Draper, 1975; Draper, 1977; Kuhnlein and Receveur, 2007), these groups regularly consumed micronutrient-rich foods such as marine fat, which were unavailable to Neanderthals.

Finally, although the incidence of dental caries has been rarely documented in prehistoric human populations, they have been identified in some Neanderthal specimens from the Mediterranean coastlines (Lalueza et al., 1993; Tillier et al., 1995; Trinkaus et al., 2000; Lebel and Trinkaus, 2001; Walker et al., 2011). Walker et al. (2011) suggested that the greater availability of fruits and sugar-rich plant organs in warmer environments may be responsible for the development of caries lesion in these southern Neanderthals.

Although paleopathology records do not provide information on bulk diets, they can be extremely helpful in evaluating the overall nutritional status of a population, especially when taking into account stress indicators. This is particularly valuable for those species, such as Neanderthals, that faced severe climatic fluctuations and inhabited highly seasonal environments. 


\section{DISCUSSION}

Neanderthal studies have been periodically influenced by historical trends, introducing biased perspectives on their behavior, diet and subsistence strategies (Ready, 2010). Early investigations mostly focused on comparisobs between Neanderthal and modern human morphology, ignoring the importance of diet in understanding the biology, ecology, and evolution of hominin species. It is only during the second half of the twentieth century that scholars have focused their attention on Neanderthal behavior and Neanderthal subsistence strategies, by integrating new archaeological approaches with the concept of adaptation. What we know today about Neanderthal diet mostly derives from the analysis of faunal assemblages, lithic industries, and isotopic signatures from bones and teeth. According to these studies, Neanderthals relied almost exclusively on meat from large and medium-sized terrestrial herbivores, while the use of other food sources, such as fish, birds, and plant materials, did not significantly contribute to their daily diets (e.g., Patou-Mathis, 2000; Burke, 2004; Hockett and Haws, 2005; Richards and Trinkaus, 2009). However, the concept of a homogenous Neanderthal diet contrasts with their vast geographical range and large chronological time frame. This extensive chronogeographic variation, coupled with the strong climatic fluctuations of the Pleistocene, not only exposed Neanderthals to very different environmental conditions over time and space, but also to high variations in food diversity (Pérez- Pérez et al., 2003; Hardy, 2010; Fiorenza et al., 2011b).

A narrow dietary spectrum largely based on the consumption of meats from large terrestrial game could have been detrimental for several reasons. First, according to Hockett and Haws (2005) a highly carnivorous diet would have resulted in an inadequate intake of some essential micronutrients and overconsumption of others. A diet lacking in essential nutrients may affect health over the short term, becoming particularly critical during pregnancy and lactation. As mentioned above, some modern human groups like the Inuit have no micronutrient deficiencies despite a low-diversified diet (e.g., Wei Wo and Draper, 1975; Draper, 1977; Kuhnlein and Receveur, 2007), but the micronutrient-rich marine fats that make up a large portion of Inuit diet were not available to Neanderthals. Secondly, although animal proteins have a number of nutritional benefits, they must be limited to no more than 35-40\% of energy (Cordain et al., 2000; Hardy, 2010). Exceeding this protein ceiling provokes negative physiological effects that lead to a condition known as "rabbit starvation," distinguished by initial symptoms of nausea and fatigue, followed by diarrhea, and then death (Speth and Spielmann, 1983). Under these circumstances, the liver is unable to eliminate the nitrogen surplus as urea produced by an unbalanced high protein intake, causing hyperammonemia (an excess of ammonia in the blood) and hyperaminoacidemia (an excess of amino acids in the blood stream), which in turn will likely result in rabbit starvation (Rudman et al., 1973). Moreover, the consequence of a diet mostly consisting of lean meats (with low intramuscular fat), can result in vitamin $\mathrm{C}$ deficiency and loss of serum calcium through urine (known as hypercalciuria), which in turn lead to bone mass reduction, increase in bone fragility, and scurvy (Lutz, 1984).

To prevent protein toxicity, modern hunter-gatherers adopted different strategies, by increasing the intake of dietary fat from animal foods, or by implementing plant foods in their daily diets (Cordain et al., 2000). Inuit for example, compensated for the protein excess of their diets by introducing large amounts of fat from fish and marine mammals (e.g., Heinbecker, 1928; Sinclair, 1953; Lester and Shapiro, 1968). The quantity of lean meat consumed by these northern foragers never surpassed $35 \%$ of their total calorific intake: their diet was primarily composed of fat and some carbohydrates obtained from berries and fermented stomach contents of reindeer and ptarmigan (Speth, 2012).

However, most of the terrestrial herbivores hunted by Neanderthals are thought to have had low proportions of fat relative to modern domestic counterparts (Mann, 2000; Hardy, 2010). Thus, Neanderthals must have compensated the ingestion of lean meat by eating carbohydrates, or by hunting animals rich in fat (Speth and Spielmann, 1983). Neanderthals may have targeted animals particularly rich in body fat (such as ungulate females in autumn), and selected fatty body parts, such as the brain, internal organs and marrow (Speth, 2012). The discovery of fractured animal bones with cutmarks in many Neanderthal sites, suggests intentional butchering for marrow extraction (high in monounsaturated fatty acids; e.g., Gaudzinski and Roebroeks, 2000; Mann, 2000; Stringer et al., 2008; Niven et al., 2012). Yet, some suggest that Neanderthals extracted lipid sources directly from bone gnawing and chewing (Marean, 2005; Costamagno, 2013), and from bone-boiling (Speth, 2012). However, deposits of fat from wild terrestrial mammals probably were not sufficient to meet Neanderthals' nutritional needs (Hardy, 2010, Speth, 2012). Moreover, extracting marrow from crushing and chewing bones, as seen in Inuit, creates large enamel chipping areas on postcanine teeth (Turner and Cadien, 1969); microtrauma patterns not frequent in Neanderthal dentition (Fiorenza, personal communication). Yet, indications of bone-boiling, such as fire-cracked rock, are absent from Middle Paleolithic sites, and cooking bones in perishable containers without using heated stones (Speth, 2012 ) is a suggestive hypothesis that needs more evidence. Finally, only sporadic episodes of fish and marine mammals consumption (mostly confined to Mediterranean coastline sites), evidence the possible intake of alternative animal fat food sources (see Table A1 in Appendix), and no paleopathological markers for scurvy, that would have indicated a dietary deficiency of vitamin $\mathrm{C}$, have been found on Neanderthal skeletal remains (Nielsen-Marsh et al., 2005). Thus, a heavy reliance on lean meat would have required more energy to satisfy metabolic functions, but it would not solve the problem of a protein ceiling above which rabbit starvation may originate (Mann, 2000).

A deficiency in micronutrients such as vitamin A, C, and $\mathrm{E}$, could have influenced the demographic trends in Neanderthal populations, by increasing the maternal and fetal-to-infant mortality rates (Hockett and Haws, 2005). Very high intake of proteins and lean meat could also be toxic for pregnant women leading to premature births, low birth-weights of newborns and short term health consequences for the offspring (Speth, 2010). Hockett (2012) evaluated the nutritional consequences of a high protein diet on pregnant Neanderthal women, suggesting that an intake of 5500 calories of exclusively terrestrial mammal parts per day would have killed the mothers and their developing fetuses. Accordingly, to avoid food poisoning from diets high in lean meat, Neanderthals must have utilized a greater diversity of food types, including plant materials (Hockett and Haws, 2005; Hardy, 2010; Hockett, 2012). 
Evidence for the exploitation of a broader dietary spectrum in Neanderthals is now emerging from new archaeological discoveries and from the application of new approaches to palaeodietary reconstructions. The recovery of edible plant remains, such as legumes, acorns and pistachios from Near Eastern Middle Paleolithic sites, suggests that Neanderthals from more temperate environments consumed a wide variety of plant materials (Albert et al., 2000; Madella et al., 2002; Lev et al., 2005). The analysis of microfossil plants trapped in the dental calculus, together with microscopic data from stone tools, suggested that even Neanderthals from cold environments exploited a variety, albeit more limited, of plant foods such as fruits, grass seeds, and underground storage organs (Hardy, 2004, 2010; Hardy and Moncel, 2011; Hardy et al., 2001, 2013; Hardy et al., 2012; Henry et al., 2011, 2014). Underground storage organs (USOs), in particular, would have offered Neanderthals a valuable alternative food source. USOs are available year-round and rich in carbohydrates, helping to meet nutritional needs, especially during cold periods (e.g. Hardy, 2010). Dental wear studies, both at the microscopic and macroscopic levels, have shown complex Neanderthal dietary scenarios depending upon the ecogeographic context, indicating the exploitation of a wide range of different foods including plant materials (e.g., Pérez-Pérez et al., 2003; El Zaatari et al., 2011; Fiorenza et al., 2011b; Harvati et al., 2013; Hlusko et al., 2013). Similarly, analyses of the archaeological record have revealed that Neanderthal feeding strategies were influenced by climatic and environmental changes, showing the integration of fast-small animals and aquatic resources at southern latitudes (e.g., Stringer et al., 2008; Brown et al., 2011; Colonese et al., 2011; Finlayson et al., 2012; Fa et al., 2013; Salazar-García et al., 2013). Ultimately, the exploitation of various food sources challenges one of the most cited hypotheses about the demise of Neanderthals, which views a narrow dietary breadth, when compared to $\mathrm{AMH}$, as one of the major causes of their extinction (Hockett and Haws, 2005).

Although, the study of faunal assemblages, lithic industries, and stable isotopic signatures are undoubtedly valuable tools in the reconstruction of subsistence strategies for past human populations, they have their methodological limitations and cannot provide the basis for an understanding of the complete dietary spectrum. Indeed, because bones typically preserve better than plants, conclusion based on the archaeological record will tend to underestimate plant consumption, and may naturally lead to the bias that meat was necessarily the primary source of food (Mann, 1981; Hastorf, 1988). In addition, because the relationship between food source and consumer is nonlinear, it is difficult to accurately estimate the percentage of meat versus plant proteins from $\delta^{15} \mathrm{~N}$ (Hedges and Reynards, 2007; Bocherens, 2009). Thus, as animal resources have a higher protein fraction than those of plant foods, isotopic studies of bone collagen will be overrepresented by animal proteins relative to vegetable proteins (Sponheimer and Lee-Thorp, 2007).

Because the reconstruction of past human diets is influenced by a growing number of factors, each with their own advantages and limitations, we believe that the application of a holistic approach will result in a better understanding of the ecologies and subsistence strategies of extinct/ancient human populations. This is particularly true for the Neanderthals, who colonized a multitude of different habitats and lived over a wide time span, characterized by a great climatic variability. Geographic and chronological variation among Neanderthal populations must be considered before drawing conclusions on their subsistence strategies. Moreover, because the Mid-Late Pleistocene was characterized by strong climatic fluctuations, which in turn drove to local extinctions and migrations of many mammalian species and the expansion/contraction of the vegetation cover, paleoenvironmental reconstructions are essential if we are to place Neanderthal groups in the correct eco-geographic context. As suggested by Hardy (2004) and Fiorenza (2015), when considering the environmental scenario of a particular fossil site, small-scale geographical variability should be taken into account as well. The presence of a river, the heterogeneous topographic pattern of a specific landscape, or the proximity to shoreline areas, may have provided favorable microhabitats offering alternative food sources, even under harsh climatic conditions.

The best approach to determining Neanderthal ecology would be to integrate and combine evidence from different diet reconstruction methods. As noted previously, all methods now used for obtaining information about past human diets have their limitations. For example, while dental microwear and macrowear studies can tell if a population relied heavily on meat, they are unable to differentiate between marine and terrestrial animal proteins, or between the consumption of large and small mammals. However, distinct isotopic signatures can help to detect this information, and can tell if a specific human population relied more on aquatic resources or not.

Few approaches to the study of Neanderthal diet have combined stable isotopes with zooarchaeological data (Bocherens et al., 1999, 2005), and dental microwear signatures (Ecker et al., 2013). One recent example of such an integrative approach is represented by a recent study on Neanderthal remains from central and southern Mediterranean Iberia (Salazar-García et al., 2013), in which the authors reconstructed the diet of this group by combing zooarchaeological and stable isotopic methods with phytolith and starch grain analyses on dental calculus. Thus, while certain type of foods or ecological information can be invisible if restricted to a specific technique, they can be detected by others.

Consequently, to cover the whole dietary spectrum in past and extinct human populations, scholars should not focus only on one specific method, but use a more holistic approach by integrating different palaeodietary reconstruction techniques and by considering different factors, such as geography, climate, or chronology.

\section{CONCLUSIONS}

Neanderthals occupied a vast geographical area, ranging from Western Europe to Central Siberia, across a wide temporal span. They lived during a period of great climatic variability inhabiting different environments, from warm Mediterranean evergreen habitats to cold open steppe grasslands. Neanderthals had a hunter-gatherer lifestyle: they were mobile foragers (e.g., Lieberman and Shea, 1994; Shea, 2007; Richards et al., 2008a) who had a sophisticated knowledge of their natural surroundings, and were able to broadly identify the nutritional and medical values of a wide range of plants (Henry et al., 2011; Hardy et al., 2012). Although Neanderthals have been traditionally portrayed as top predators, with a diet based on meat, several studies demonstrate that there is a physiological limit on the amount of animal proteins that can be consumed. Also, new archaeological evidence and the use of advanced palaeodietary reconstruction methods, such as the use of 
THE DIET OF THE NEANDERTHALS

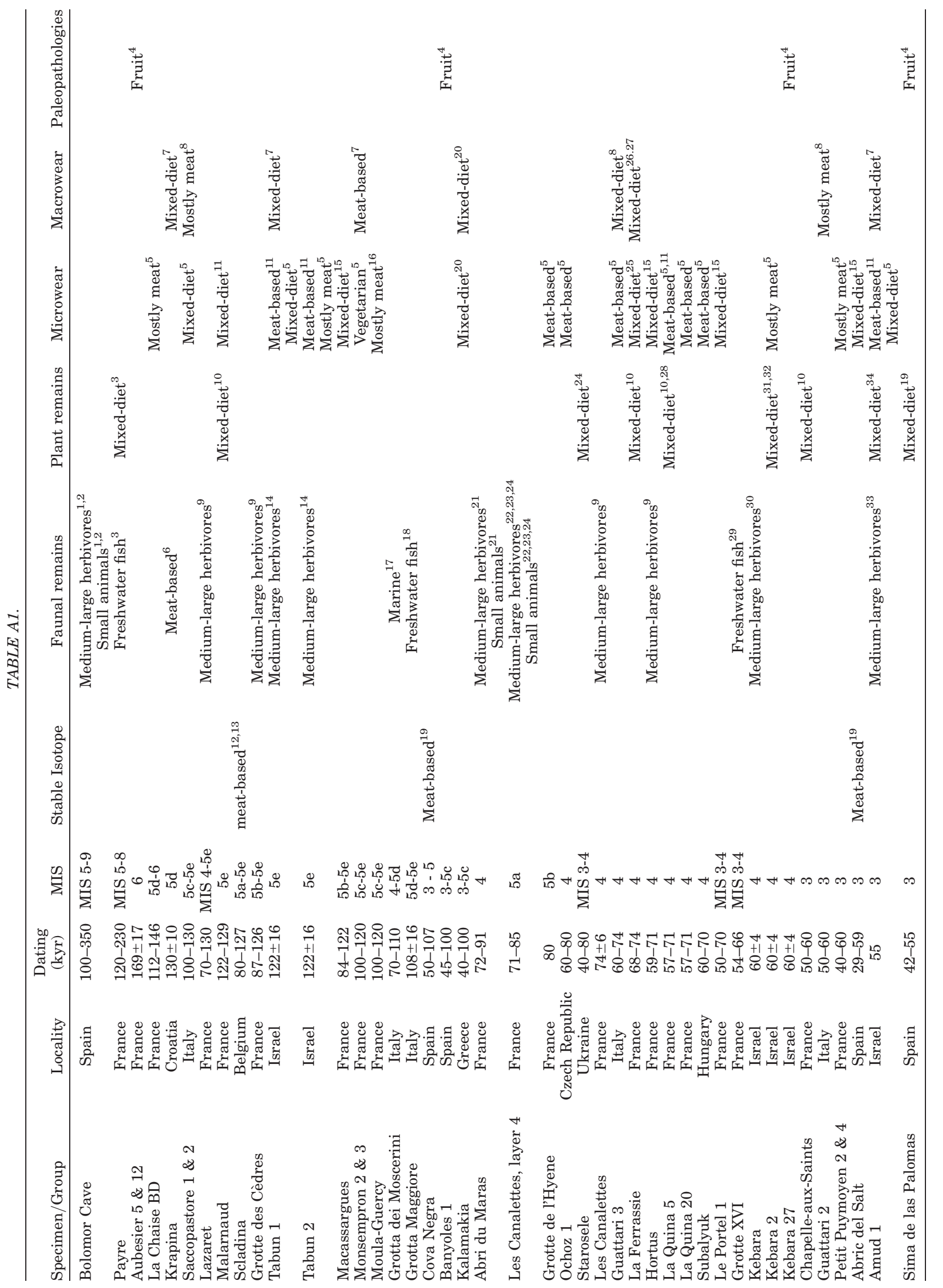




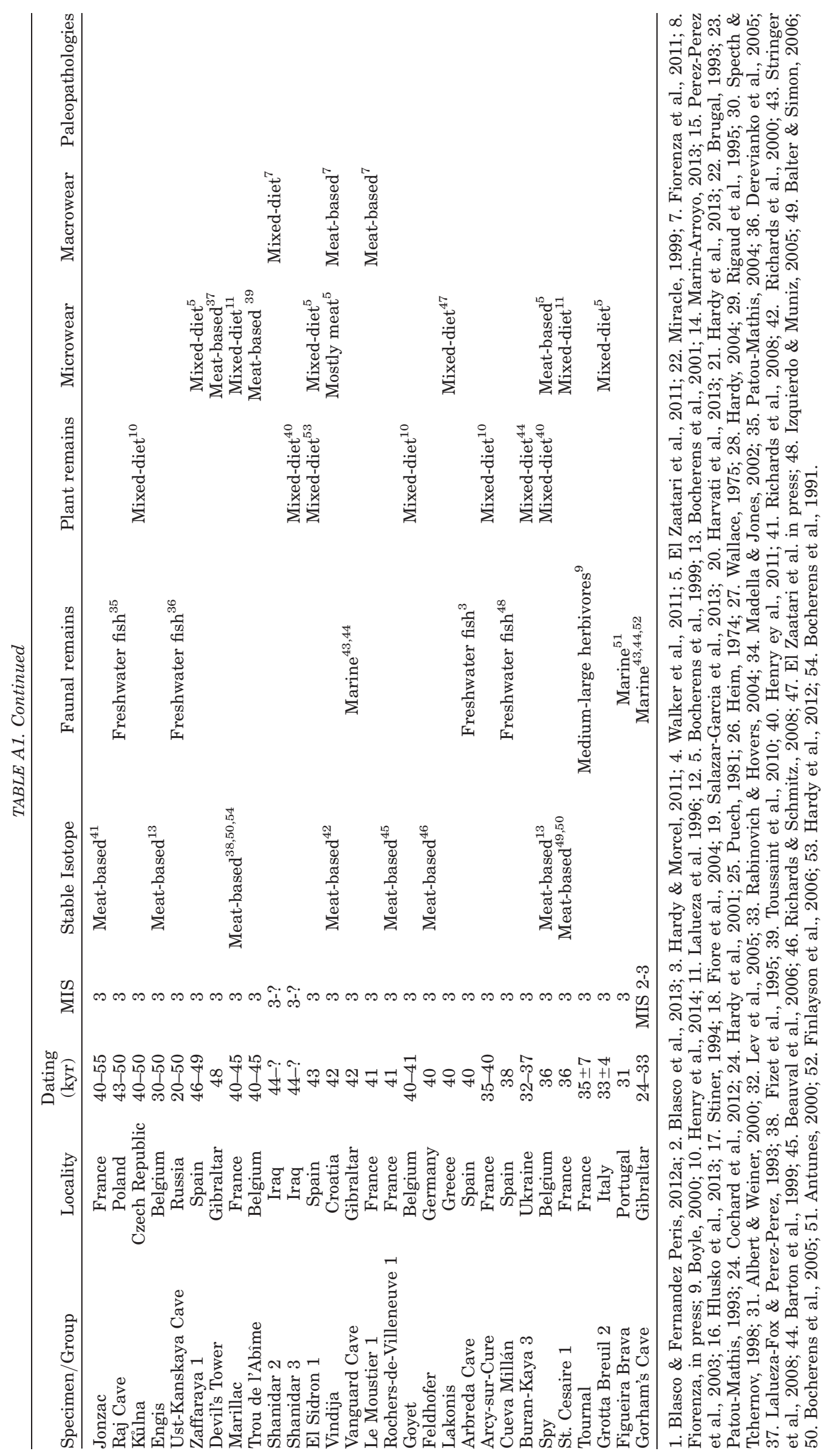


faecal biomarkers (Sistiaga et al., 2014), show that Neanderthals had a much more complex diet than previously thought, and exploited a wide variety of foods, including small mammals, birds, fish and marine animals, and a large range of plants. Neanderthal's use of a broad dietary spectrum opens new questions on their ecology, biology, and subsistence strategies, and requires us to rethink the competition hypothesis with anatomically modern humans.

\section{ACKNOWLEDGMENTS}

The authors would like to thank Alfred Sanchis Serra, Michael P. Richards, and Jean-Jacques Hublin.

\section{APPENDIX}

Table A1. List of Neanderthal specimens and Neanderthal fossil sites with information about diet derived from the following methods: stable isotope, faunal remains, plant remains, dental microwear and macrowear, and paleopathology.

\section{LITERATURE CITED}

Addy M, Shellis RP. 2006. Interaction between attrition, abrasion and erosion in tooth wear. Monogr Oral Sci 20:17-31.

Albert RM, Lavi O, Estroff L, Weiner S, Tsatskin A, Ronen A, Lev-Yadun S. 1999. Mode of occupation of Tabun Cave, Mt. Carmel, Israel, during the Mousterian period: a study of the sediments and phytoliths. J Arch Sci 26:1249-1260.

Albert RM, Weiner S, Bar-Yosef O, Meignen L. 2000. Phytoliths in the Middle Palaeolithic deposits of Kabara Cave, Mt. Carmel, Israel: study of the plant materials used for fuel and other purposes. J Archaeol Sci 27:931-947.

Allen JRM, Brandt U, Brauer A, Hubberten H, Huntley B, Keller J, Kraml M, Mackensen A, Mingram J, Negendank JFW, Nowaczyk NR, Oberhänsli H, Watts WA, Wulf S, Zolitschka B. 1999. Evidence of rapid last glacial environmental fluctuations from southern Europe. Nature 400:740-743.

Álvarez-Lao DJ, García N. 2011a. Geographical distribution of Pleistocene cold-adapted large mammal faunas in the Iberian Peninsula. Quatern Int 233:159-170.

Álvarez-Lao DJ, García N. 2011b. Southern dispersal and Palaeoecological implications of woolly rhinoceros (Coelodonta antiquitatis): review of the Iberian occurrences. Quatern Sci Rev 30:2002-2017.

Ambrose SH. 1990. Preparation and characterization of bone and tooth collagen for isotopic analysis. J Archaeol Sci 17: 431-451.

Ambrose SH, Buikstra JE, Krueger HW. 2003. Status and gender differences in diet at Mound 72, Cahokia, revealed by isotopic analysis of bone. J Anthropol Archaeol 22:217-226.

Ambrose SH, Norr L. 1993. Experimental evidence for the relationship of the carbon isotope ratios of whole diet and dietary protein to those of bone collagen and carbonate.In: Lambert JB, Gruppe G, editors. Prehistoric human bone: archaeology at the molecular level. Berlin: Springer Verlag. p 1-37.

Antoine P, Rousseau DD, Degeai JP, Moine O, Lagroix F, Kreutzer S, Fuchs M, Hatté C, Gauthier C, Svoboda J, Lisá L. 2013. High-resolution record of the environmental response to climatic variations during the Last InterglacialeGlacial cycle in Central Europe: the loess-palaeosol sequence of Dolní Vestonice (Czech Republic). Quatern Sci Rev 67:17-38.

Auguste P. 1995. Cadres biostratigraphique et paléoécologique du peuplement humain dans la France septentrionale durant la Pléistocène. Apports de l'étude paléontologique des grands mammifères du gisement de Biache-Saint-Vaast (Pas-de-Calais). Ph.D. Thesis, unpublished. Paris: Muséum national d'histoire naturelle. p 1924.

Badenhuizen NP. 1969. The biogenesis of starch granules in higher plants. New York: Appleton-Century-Crofts.
Bailey S, 2002. A closer look at Neanderthal postcanine dental morphology: the mandibular dentition. Anat Rec 269:148156.

Bailey SE. 2004. A morphometric analysis of maxillary molar crowns of Middle-Late Pleistocene hominins. J Hum Evol 47: 183-198.

Bailey SE, Benazzi S, Souday C, Astorino C, Paul K, Hublin JJ. 2014. Taxonomic differences in deciduous upper second molar crown outlines of Homo sapiens, Homo neanderthalensis, and Homo erectus. Am J Phys Anthropol 72:1-9.

Bardají T, Goy JL, Zazo C, Hillaire-Marcel C, Dabrio CJ, Cabero A, Ghaleb B, Silva PG, Lario J. 2009. Sea level and climate changes during OIS $5 \mathrm{e}$ in the Western Mediterranean. Geomorphology 104:22-37.

Barton RNE, Currant AP, Fernãndez-Jalvo Y, Finlayson JC, Goldberg P, Macphail R, Pettitt PB, Stringer CB. 1999. Gibraltar Neanderthals and results of recent excavations in Gorham's, Vanguard and Ibex caves. Antiquity 73:13-23.

Bar-Yosef O. 2004. Eat what is there: hunting and gathering in the world of Neanderthals and their neighbours. Int J Osteoarchaeol 14:333-342.

Beauval C, Lacrampe-Cuyaubere F, Maureille B, Trinkaus E. 2006. Direct radiocarbon dating and stable isotopes of the Neandertal femur from Les Rochers de Villeneuve. Bull Mém Soc Anthropol Paris18:35-42.

Behre KE. 1989. Biostratigraphy of the last glacial period in Europe. Quatern Sci Rev 8:25-44.

Behrensmeyer AK. 1978. Taphonomic and ecologic information from bone weathering. Paleobiology 4:150-162.

Benazzi S, Bailey SE, Peresani M, Mannino MA, Romandini M, Richards MP, Hublin J-J. 2014a. Middle Paleolithic and Uluzzian human remains from Fumane Cave, Italy. J Hum Evol. 70:61-68.

Benazzi S, Coquerelle M, Fiorenza L, Bookstein F, Katina S, Kullmer O. 2011a. Comparison of dental measurement systems for taxonomic assignment of first molars. Am J Phys Anthropol 144:342-354.

Benazzi S, Douka K, Fornai C, Bauer CC, Kullmer O, Svoboda J, Pap I, Mallegni F, Bayle P, Coquerelle M, Condemi S, Ronchitelli A, Harvati K, Weber GW. 2011b. Early dispersal of modern humans in Europe and implications for Neanderthal behaviour. Nature 479: 525-528.

Benazzi S, Fornai C, Buti L, Toussaint M, Mallegni F, Ricci S, Gruppioni G, Weber G, Condemi S, Ronchitelli A. 2012. Cervical and crown outline analysis of worn Neanderthal and modern human lower second deciduous molars. Am J Phys Anthropol 149:537-546.

Benazzi S, Peresani M, Talamo S, Fu Q, Mannino MA, Richards MP, Hublin J-J. 2014b. A reassessment of the presumed Neandertal human remains from San Bernardino Cave, Italy. J Hum Evol 66:89-94.

Berger T, Trinkaus E. 1995. Patterns of trauma among the Neanderthals. J Archaeol Sci 22:841-852.

Bermúdez de Castro JM, Bromage TG, Fernández Jalvo Y. 1988. Labial striations on fossil human anterior teeth: evidence of handedness in the middle and early Upper Pleistocene. J Hum Evol 17:403-412.

Bermúdez de Castro JM, Martinón-Torres M, Blasco R, Rosell J, Carbonell E. 2013. Continuity or discontinuity in the European Early Pleistocene human settlement: the Atapuerca evidence. Quatern Sci Rev 76:53-65.

Binford LR. 1981. Bones: ancient Men and Modern Myths. New York: Academia Press. p 440.

Blanshard JMV. 1987. Starch granule structure and function: a physicochemical approach.In: Galliard T, editor. Starch: properties and potential. New York: Wiley. p 16-54.

Blasco R, Blain HA, Rosell J, Carlos Díez J, Huguet R, Rodríguez J, Arsuaga JL, Bermúdez de Castro JM, Carbonell E. 2011. Earliest evidence for human consumption of tortoises in the European Early Pleistocene from Sima del Elefante, Sierra de Atapuerca, Spain. J Hum Evol 61:503-509.

Blasco R, Fernández Peris J. 2012a. A uniquely broad spectrum diet during the Middle Pleistocene at Bolomor Cave (Valencia, Spain). Quatern Int 252:16-31. 
Blasco R, Fernández Peris J. 2012b. Small and large game: Human use of diverse faunal resources at Level IV of Bolomor Cave (Valencia, Spain). C R Palevol 11:265-282.

Blasco R, Peris JF. 2009. Middle Pleistocene bird consumption at Level XI of Bolomor Cave (Valencia, Spain). J Archaeol Sci 36:2213-2223

Blasco R, Rosell J, Arsuaga JL, Bermúdez de Castro JM, Carbonell E. 2010. The hunted hunter: the capture of a lion (Panthera leo fossilis) at the Gran Dolina site, Sierra de Atapuerca, Spain. J Archaeol Sci 37:2051-2060.

Blasco R, Rosell J, Fernández Peris J, Arsuaga JL, Bermúdez de Castro JM, Carbonell E. 2013. Environmental availability, behavioural diversity and diet: a zooarchaeological approach from the TD10-1 sublevel of Gran Dolina (Sierra de Atapuerca, Burgos, Spain) and Bolomor Cave (Valencia, Spain). Quatern Sci Rev 70:124-144.

Bocherens H, Drucker D. 2003. Trophic level isotopic enrichment of carbon and nitrogen in bone collagen: case studies from recent and ancient terrestrial ecosystems. Int $J$ Osteoacrhaeol 13:46-53.

Bocherens H. 2009. Neanderthal dietary habits: review of the isotopic evidence.In: Hublin, JJ, Richards M, editors. The evolution of hominid diets: integrating approaches to the study of Palaeolithic subsistence. New York: Springer. p 241-250.

Bocherens H, Billiou D, Mariotti A. 1999. Palaeoenvironmental and palaeodietary implications of isotopic biogeochemistry of last interglacial Neanderthal and mammal bones in Scladina Cave (Belgium). J Archaeol Sci 26:599-607.

Bocherens H, Billiou D, Mariotti A, Toussaint M, Patou-Mathis M, Bonjean D, Otte M. 2001. New isotopic evidence for dietary habits of Neandertals from Belgium. J Hum Evol 40:497-505.

Bocherens H, Drucker D, Billiou D, Patou-Mathis M, Vandermeersch B. 2005. Isotopic evidence for diet and subsistence pattern of the Saint-Cèsaire I Neanderthal: review and use of a multi-source mixing model. J Hum Evol 49:71-87.

Bocherens H, Drucker DG, Madelaine S. 2014. Evidence for a ${ }^{15} \mathrm{~N}$ positive excursion in terrestrial foodwebs at the Middle to Upper Palaeolithic transition in south-west France: implications for early modern human palaeodiet and palaeoenvironment. J Hum Evol 69:31-43.

Bocherens H, Fizet M, Mariotti A, Lange-Badre B, Vandermeersch B, Borel JP, Bellon G. 1991. Isotopic biogeochemistry $\left({ }^{13} \mathrm{C},{ }^{15} \mathrm{~N}\right)$ of fossil vertebrate collagen: application to the study of a past food web including Neandertal man. J Hum Evol 20:481-492.

Boëda E. 1994. Le Concept Levallois: Variabilitè des Méthodes. Paris: Centre de la Recherche Scientifique (CNRS).

Bol R, Pflieger C. 2002. Stable isotope (13C, 15N and 34S) analysis of the hair of modern humans and their domestic animals. Rapid Commun Mass Spectrom 16:2195-2200.

Bordes F. 1961. Typologie du Paléolitique ancien et moyen. Paris: Centre de la Recherche Scientifique (CNRS).

Brace CL. 1967. Environment, tooth form, and size in the pleistocene. J Dent Res 46:809-816.

Brace CL, Ryan AS, Smith BH. 1981. Comment to Tooth wear in La Ferrassie man. Curr Anthropol 22:424-430.

Britton K, Gauzinski-Windheuser S, Roebroeks W, Kindler L, Richsrda MP. 2011. Stable isotope analysis of well-preserved 120,000-year-old herbivore bone collagen from the Middle Palaeolithic site of Neumark-Nord 2, Germany reveals niche separation between bovids and equids. Palaeogeog Palaeocl 333-334:168-177.

Brown K, Fa D, Finlayson G, Finlayson C. 2011. Small game and marine resource exploitation by Neanderthals: the evidence from Gibraltar.In: Bicho NF, Haws JA, Davis LG, editors. Trekking the shore. New York: Springer. p 247-272.

Brown TA, Nelson DE, Vogel JS, Southon JR. 1988. Improved collagen extraction by modified Longin method. Radiocarbon 30:171-177.

Burke A., 2004. The ecologyof Neanderthals: preface. Int J Osteoarchaeol 14:155-161.

Cacho I, Grimalt JO, Pelejero C, Canals M, Sierro FJ, Flores JA, Shackleton N. 1999. Dansgaard-Oeschger and Heinrich event imprints in Alboran Sea paleotemperatures. Paleoceanography 14:698-705.

Calley S, Grace R. 1988. Drill bits from Kumartepe, Turkey, Vol. 411. In: Beyries, S. editor. Industries lithique: tracéologie et technologie. Oxford: BAR International series. p 69-82.

Callow P, Conford JM. 1986. La Cotte de St. Brelade 1961-1978: excavation by C. B. M. McBurney. Noewich: Kluwer Academic Publishers.

CAPE - Last Interglacial, Project Members, 2006. Last Interglacial Arctic warmth confirms polar amplification of climate change. Quatern Sci Rev 25:1383-1400.

Cerling TE. 1999. Palaeorecords of C4 plants and ecosystems.In: Sage RF, Monson RK, editors. $\mathrm{C}_{4}$ Plant Biology. London: Academic Press. p 313-373.

Chisholm BS, Nelson DE, Schwarcz HP. 1982. Stable carbon isotope ratios as a measure of marine versus terrestrial protein in ancient diets. Science 216:1131-1132.

Churchill SE. 2006. Bioenergetic perspectives on Neanderthal thermoregulatory and activity budgets.In: Harvati K, Harrison T, editors. Neanderthals revisited: new approaches and perspectives. Dordrecht, The Netherlands: Springer. p 113114.

Cochard D. 2004. Les léporidés dans la subsistance paléolithique du sud de la France. Ph.D. Thesis, unpublished. Talence: Université Bordeaux 1.

Cochard D, Brugal JP, Morin E, Meignen L. 2012. Evidence of small fast game exploitation in the Middle Paleolithic of Les Canalettes Aveyron, France. Quatern Int 264:32-51.

Colonese AC, Mannino MA, Bar-Yosef Mayer DE, Fa DA Finlayson JC, Lubell D, Stiner MC. 2011. Marine mollusc exploitation in Mediterranean prehistory: an overview. Quatern Int 239:86-103.

Conard NJ, Prindiville TJ. 2000. Middle palaeolithic hunting economies in the Rhineland. Int J Osteoarchaeol 10:286-309.

Condemi S. 2006. Continuity and/or Discontinuity in the Pleistocene peopling of Europe? Hum Evol 21:251-259.

Cordain L, Brand Miller J, Eaton SB, Mann N, Holt SHA, Speth JD. 2000. Plant-animal subsistence ratios and macronutrient energy estimations in worldwide hunter-gatherer diets. Am J Clin Nutr 71:682-692.

Cortella AR, Pochettino ML. 1994. Starch grain analysis as a microscopic diagnostic feature in the identification of plant material. Econ Bot 48:171-181.

Costamagno S. 2013. Bone grease rendering in Mousterian contexts: the case of Noisetier Cave (Fréchet-Aure, HautesPyrénées, France).In: Clark JL, Speth JD, editors. Zooarchaeology and modern human origins: human hunting behavior during the Later Pleistocene. New York: Springer. p 209-225.

Costamagno S, Laroulandie V. 2004. L'exploitation des petits vertébrés dans les Pyrénées françaises du Paléolithique au Mésolithique: un inventaire taphonomique et archozoologique. In: Brugal JP, Desse J, editors. Petits animaux et sociétés humaines. Du complément alimentaire aux ressources utilitaires. Antibes: APCDA. p 369-382.

Costamagno S, Liliane M, Cédric B, Bernard V, Bruno M. 2006. Les Pradelles (Marillac-le-Franc, France): a mousterian reindeer hunting camp? J Anthropol Archaeol 25:466-484.

Dansgaard W, Johnsen S, Clausen HB, Dahl-Jensen D, Gundestrup N, Hammer CU, Oeschger H. 1984. North Atlantic climatic oscillations revealed by deep Greenland ice cores.In: Hansen JE, Takahashi T, editors. Climate processes and climate sensitivity. Washington DC: American Geophysical Union. p 288-298.

Daujeard C, Fernandes P, Guadelli JL, Moncel MH, Santagata C, Raynal JP. 2012. Neanderthal subsistence strategies in Southeastern France between the plains of the Rhone Valley and the mid-mountains of the Massif Central (MIS 7 to MIS 3). Quatern Int 252:32-47.

De Niro MJ. 1985. Postmortem preservation and alteration of in vivo bone collagen isotope ratios in relation to palaeodietary reconstruction. Nature 317:806-809.

De Niro MJ, Epstein S. 1981. Influence of diet on the distribution of nitrogen isotopes in animals. Geochim Cosmochim Acta 49:97-115. 
Discamps E, Jaubert J, Bachellerie F. 2011. Human choices and environmental constraints: deciphering the variability of large game procurement from Mousterian to Aurignacian times (MIS 5-3) in southwestern France. Quatern Sci Rev 30:2755-2775.

Domínguez-Rodrigo M, Pickering TR. 2003. Early hominid hunting and scavenging: a zooarcheological review. Evol Anthropol 12:275-282.

Douglas GD, DeVreugd RT. 1997. The dynamics of occlusal relationships.In McNeill C, editor. Science and Practice of Occlusion. Illinois: Quintessence Publishing. p 69-78.

Draper HH. 1977. The aboriginal Eskimo diet in modern perspective. Am Anthropol 79:309-316.

Ecker M, Bocherens H, Julien M-A, Rivals F, Raynal JP, Moncel M-H. 2013. Middle Pleistocene ecology and Neanderthal subsistence: insights from stable isotope analyses in Payre (Ardèche, southeastern France). J Hum Evol 65:363373.

Eerkens JM, Berget AG, Bartelink EJ. 2011. Estimating weaning and early childhood diet from serial micro-samples of dentin collagen. J Archaeol Sci 38:3101-3111.

Ehlers J, Gibbard PL, Hughes PDE. 2011. Quaternary glaciations, extent and chronology, developments in quaternary sciences. Great Britain: Elsevier.

El Zaatari S. 2010. Occlusal microwear texture analysis and the diets of historical/prehistoric hunter-gatherers. Int J Osteoarchaeol 20:67-87.

El Zaatari S, Grine FE, Ungar PS, Hublin JJ. 2011. Ecogeographic variation in Neandertal dietary habits: evidence from occlusal microwear texture analysis. J Hum Evol 61:411-424.

El Zaatari S, Harvati K, Panagopoulou E. Occlusal molar microwear texture analysis: the method and its application for the dietary reconstruction of the Lakonis Neandertal. In: Voutsaki S, Valamoti SM, editors. Subsistence, Economy and Society in the Greek World. Louvain: Peeters Publishers. In press.

Elliot M, Labeyrie L, Dokken T, Manthé S. 2001. Coherent patterns of ice-rafted debris deposits in the Nordic regions during the last glacial (10-60 ka). Earth Planet Sci Lett 194: $151-163$.

Estabrook VH. 2009. Sampling biases and new ways of addressing the significance of trauma in Neandertals. $\mathrm{PhD}$ dissertation. University of Michigan, Ann Arbor.

Fa JE, Stewart JR, Lloveras L, Vargas JM 2013. Rabbits and hominin survival in Iberia. J Hum Evol 64:233-241.

Fabre V, Condemi S, Degioanni A, Herrscher E. 2011. Neanderthals versus modern humans: evidence for resource competition from isotopic modelling. Int J Evol Biol doi:10.4061/2011/ 689315.

Fahy G, Richards M, Riedel J, Hublin J-J, Boesch C. 2013. Stable isotope evidence of meat eating and hunting specialization in adult male chimpanzees. Proc Natl Acad Sci USA 110: $5829-5833$

Fiore I, Gala M, Tagliacozzo A. 2004. Ecology and subsistence strategies in the Eastern Italian Alps during the Middle Palaeolithic. Int J Osteoarchaeol 14:273-286.

Fiorenza L. 2015. Reconstructing diet and behaviour of Neanderthals from Central Italy through dental macrowear analysis. J Anthropol Sci. 93:1-15.

Fiorenza L, Benazzi S, Kullmer O. 2011a. Para-masticatory wear facets and their functional significance in huntergatherer maxillary molars. J Archaeol Sci 38:2182-2189.

Fiorenza L, Benazzi S, Tausch J, Kullmer O, Bromage TG, Schrenk F. 2011b. Molar macrowear reveals Neanderthal ecogeographic dietary variation. PLoS One 6:1-11.

Fiorenza L, Benazzi S, Viola B, Kullmer O, Schrenk F. 2011c. Relationship between cusp size and occlusal wear pattern in Neanderthal and early Homo sapiens first maxillary molars. Anat Rec 294:453-461.

Fiorenza L, Kullmer O. 2013. Dental wear and cultural behaviour in Middle Paleolithic humans from the Near East. Am J Phys Anthropol 152:107-117.

Finlayson C. 2004. Neanderthals and modern humans: an ccological and evolutionary perspective. Cambridge: Cambridge University Press.
Finlayson C, Brown K, Blasco R, Rosell J, Negro JJ, Bortolotti GR, Finlayson G, Sánchez Marco A, Giles Pacheco F, Rodríguez Vidal J, Carrión JS, Fa DA, Rodríguez Llanes JM. 2012. Birds of a feather: Neanderthal exploitation of raptors and corvids. PLoS One 7:e45927.

Finlayson C, Giles Pacheco F, Rodríguez-Vidal J, Fa DA, Gutierrez López JM, Santiago Pérez A, Finlayson G, Allué E, Baena Preysler J, Cáceres I, Carrión JS, Fernández Jalvo Y, Gleed-Owen CP, Jimenez Espejo F, López P, López Sáez JA, Riquelme Cantal JA, Sánchez Marco A, Giles Guzman F, Brown K, Fuentes N, Valarino CA, Villalpando A, Stringer CB, Martinez Ruiz F, Sakamoto T. 2006. Late survival of Neanderthals at the southernmost extreme of Europe. Nature 443:850-853.

Fischer A, Vemming Hansen P, Rasmussen P. 1984. Macro and microwear traces on lithic projectile points. Experimental results and prehistoric examples. J Danish Archaeol 3:19-46.

Fizet M, Mariotti A, Bocherens H, Lange-Badrè B, Vandersmeersch B, Borel J, Bellon G. 1995. Effect of diet, physiology and climate on carbon and nitrogen stable isotopes of collagen in late Pleistocene anthropic palaeoecosystem: Marillac, Charente, France. J Archaeol Sci 22:67-79.

Fletcher WJ, Sánchez Goñi MF, Allen JRM, Cheddadi R, Combourieu-Nebout N, Huntley B, Lawson I, Londeix L, Magri D, Margari V, Müller UC, Naughton F, Novenko E, Roucoux K, Tzedakis PC. 2010. Millennial-scale variability during the last glacial in vegetation records from Europe. Quatern Sci Rev 29:2839-2864.

Franciscus RG, Churchill SE. 2002. The costal skeleton of Shanidar 3 and a reappraisal of Neandertal thoracic morphology. J Hum Evol 42:303-356.

Fraysse F, Pokrovsky OS, Schott J, Meunier JD. 2009. Surface chemistry and reactivity of plant phytoliths in aqueous solutions. Chem Geol 258:197-206.

Fuller BT, Fuller JL, Harris DA, Hedges REM, 2006. Detection of breastfeeding and weaning in modern human infants with carbon and nitrogen stable isotope ratios. Am J Phys Anthropol 129:279-293.

Ganss C. 2006. Definition of erosion and links to tooth wear. In: Lussi A, editor. Dental Erosion. Monogr Oral Sci 20. Basel: Karger. p 9-16.

Gaudzinski S. 1995. Wallertheim revisited: A re-analysis of the fauna from the middle palaeolithic site of Wallertheim (Rheinhessen/Germany). J Archaeol Sci 22:51-66.

Gaudzinski S. 2006. Monospecific or species-dominated faunal assemblages during the Middle Palaeolithic in Europe.In: Hovers E, Kuhn S, editors. Transitions before the transition. New York: Springer. p 137-148.

Gaudzinski S, Roebroeks W. 2000. Adults only. Reindeer hunting at the Middle Palaeolithic site Salzgitter Lebenstedt, Northern Germany. J Hum Evol 38:497-521.

Gaudzinski-Windheuser S. Kindler L. 2012. Research perspectives for the study of Neandertal subsistence strategies based on the analysis of archaeozoological assemblages. Quatern Int 247:59-68.

Gaudzinski-Windheuser S, Niven L. 2009. Hominin subsistence patterns during the Middle and Late Paleolithic in northwestern Europe.In: Hublin JJ, Richards M, editors. The evolution of hominin diets. Netherlands: Springer. p 99-111.

Gómez-Olivencia A, Arceredillo D, Álvarez-Lao DJ, Garate D, San Pedro Z, Castaños P, Rios-Garaizar J. 2013. New evidence for the presence of reindeer (Rangifer tarandus) on the Iberian Peninsula in the Pleistocene: an archaeopalaeontological and chronological reassessment. Boreas 43:286-308.

Gómez-Robles A, Martinón-Torres M, Bermúdez de Castro JM, Margvelashvili A, Bastir M, Arsuaga JL, Pérez-Pérez A, Estebaranz F, Martínez LM, 2007. A geometric morphometric analysis of hominin upper first molar shape. J Hum Evol 52: 272-285.

Grace R. 1996. Use-wear analysis: the state of the art. Archaeometry 38:209-229.

Grine FE. 1986. Dental evidence for dietary differences in Australopithecus and Paranthropus: a quantitative analysis of permanent molar microwear. J Hum Evol 15:783-822. 
Guatelli-Steinberg D, Larsen CS, Hutchinson DL. 2004. Prevalence and the duration of linear enamel hypoplasia: a comparative study of Neandertals and Inuit foragers. J Hum Evol 47:65-84.

Guennouni KE. 2001. Les lapins du Pleistocène moyen et supérieur de quelques sites préhistoriques de l'Europe mediterranéenne: Terra-Amata, Orgnac 3, Baume Bonne, Grotte du Lazaret, Grotte du Boquete de Zafarraya, Arma delle Manie, étude paléontologique, taphonomique et archozoologique. Paris: Museum National d'Histoire Naturelle.

Hardy BL. 2004. Neanderthal behaviour and stone tool function at the Middle Palaeolithic site of La Quina, France. Antiquity 78:547-565.

Hardy BL. 2010. Climatic variability and plant food distribution in Pleistocene Europe: implications for Neanderthal diet and subsistence. Quatern Sci Rev 29:662-679.

Hardy BL, Kay M, Marks AE, Monigal K, 2001. Stone tool function at the paleolithic sites of Starosele and Buran Kaya III, Crimea: behavioral implications. Proc Natl Acad Sci USA 98: 10972-10977.

Hardy BL, Moncel M-H. 2011. Neanderthal use of fish, mammals, birds, starchy plants and wood 125-250,000 Years Ago. PloS one 6:e23768.

Hardy BL, Moncel M-H, Daujeard C, Fernandes P, Béarez P Desclaux E, Chacon Navarro MG, Puaud S, Gallotti R. 2013. Impossible Neanderthals? Making string, throwing projectiles and catching small game during Marine Isotope Stage 4 (Abri du Maras, France). Quatern Sci Rev 82:23-40.

Hardy K, Buckley S, Collins MJ, Estalrrich A, Brothwell D, Copeland L, García-Tabernero A, García-Vargas S, de la Rasilla M, Lalueza-Fox C, Huguet R, Bastir M, Santamaria D, Madella M, Wilson J, Fernández Cortéz Á, Rosas A. 2012. Neanderthal medics? Evidence for food, cooking, and medicinal plants entrapped in dental calculus. Naturwissenschaften 99:617-626.

Hare PE, 1980. Organic Geochemistry of bone and its relation to the survival of bone in the natural environment. In: Behrensmeye AK, Hill AP, editors. Fossils in the making: vertebrate taphonomy and paleoecology. Chicago:The University of Chicago Press. p 208-219.

Harrison SP, Sanchez Goñi MF. 2010. Global patterns of vegetation response to millennial-scale variability and rapid climate change during the last glacial period. Quatern Sci Rev 29: 2957-2980.

Harvati K, Darlas A, Bailey SE, Rein TR, El Zataari S, Fiorenza L, Kullmer O, Psathi E. 2013. New Neanderthal remains from Mani Peninsula, southern Greece: the Kalamakia Middle Paleolithic cave site. J Hum Evol 64:486-499.

Haslam M. 2004. The decomposition of starch grains in soils: implications for archaeological residue analysis. J Arch Sci 31:1715-1734.

Hastorf CA. 1988. The use of paleoethnobotanical data in prehistoric studies of crop production, processing, and consumption.In: Hastorf CA, Popper VS, editors. Current paleoethnobotany: analytical methods and cultural interpretations of archeological plant remains. Chicago: University of Chicago Press. p 119-144.

Haws J, Hockett BS. 2004. Theoretical perspectives on the dietary role of small animals in human evolution. In: Brugal JP, Desse J, editors. Petits animaux et societes humanes. Du complement alimentaire aux resources utilitaires. Antibes: APDCA. p 533-544.

Hayden B. 1979. Lithic use-wear analysis. New York: Academic Press.

Hedges REM, Clement JG, Thomas CDL, O’Connell TC, 2007. Collagen turnover in the adult femoral mid-shaft: modeled from anthropogenic radiocarbon tracer measurements. Am J Phys Anthropol 133:808-816.

Hedges REM, Reynard LM. 2007. Nitrogen isotopes and the trophic level of humans in archaeology. J Archaeol Sci 34: 1240-1251.

Heim JL. 1974. Les homes fossils de la Ferrassie (Dordogne) et le problèm de la définition des Néandertaliens classiques. III. Squelette céphalique. L’Anthropologie 78:321-378.
Heinbecker P. 1928. Studies on the metabolism of Eskimos. J Biol Chem 80:461-475.

Heinrich H. 1988. Origin and consequences of cyclic ice rafting in the northeast Atlantic Ocean during the past 130,000 years. Quatern Res 29:142-152.

Heinzelin de Braucourt J. 1962. Manuel de typologie des industries lithiques. Bruxelles: Institut Royal des Sciences Naturelles de Belgique.

Henry AG. Formation and taphonomic processes affecting starch granules. In: Marston J, d' Alpoim Guedes J, Warinner C, editors. Method and Theory in Paleoethnobotany. Colorado: University Press of Colorado. In press.

Henry AG, Brooks AS, Piperno DR. 2011. Microfossils in calculus demonstrate consumption of plants and cooked foods in Neanderthal diets (Shanidar III, Iraq; Spy I and II, Belgium). Proc Natl Acad Sci USA 108:486-491.

Henry AG, Brooks AS, Piperno DR. 2014. Plant foods and the dietary ecology of Neanderthals and early modern humans. J Hum Evol: http://dx.doi.org/10.1016/j.jhevol.2013.12.014

Henry DO, Hall SA, Hietala HJ, Demidenko YE, V U, Rosen AM, Thomas PA. 1996. Middle Paleolithic behavioral organization: 1993 excavation of Tor Faraj, Southern Jordan. J Field Arch 23:31-53.

Henry DO, Hietala HJ, Rosen AM, Demidenko YE, Usik V, Armagan TL. 2004. Human behavioral organization in the Middle Paleolithic: were Neanderthals different? Am Anthropol 106:17-31.

Hewitt G. 2000. The genetic legacy of the Quaternary ice ages. Nature 405:907-913.

Higham T, Ramsey CB, Karavanic I, FH Smith, Trinkaus E 2006. Revised direct radiocarbon dating of the Vindija G1 Upper Paleolithic Neandertals. Proc Natl Acad Sci USA 103: 553-557.

Hillson S. 2003. Dental Anthropology. Cambridge: Cambridge University Press.

Hlusko LJ, Carlson JP, Guatelli-Steinberg D, Krueger KL, Mersey B, Ungar PS, Defleur A. 2013. Neanderthal teeth from Moula-Guercy, Ardèche, France. Am J Phys Anthropol 151:477-491.

Hockett B. 2012. The consequences of Middle Paleolithic diets on pregnant Neanderthal women. Quatern Int 264:78-82.

Hockett B, Haws JA. 2005. Nutritional ecology and the human demography of Neandertal extinction. Quatern Int 137:21-34.

Holliday TW. 1994. Cranial evidence of cold adaptation in European Neandertals. Am J Phys Anthropol 104:245-258.

Howland MR, Corr LT, Young SMM, Jones V, Jim S, Van der Merwe NJ, Mitchell AD, Evershed RP. 2003. Expression of the dietary isotope signal in the compound-specific delta-13 values of pig bone lipids and amino acids. Int J Osteoarchaeol 13:54-65.

Hublin JJ, Roebroeks W. 2009. Ebb and flow or regional extinctions? On the character of Neandertal occupation of northern environments. C R Palevol 8:503-509.

Huguet R, Saladié P, Cáceres I, Díez C, Rosell J, Bennàsar M, Blasco R, Esteban-Nadal M, Gabucio MJ, Rodríguez-Hidalgo A, Carbonell E. 2013. Successful subsistence strategies of the first humans in south-western Europe. Quatern Int 295:168182.

Hutchinson DL, Larsen CS, Choi I. 1997. Stressed to the max? Physiological perturbation in the Krapina Neandertals. Curr Anthropol 38:904-914.

Iacumin P, Nikolaev V, Ramigni M. 2000. C and N stable isotope measurements on Eurasian fossil mammals, 40000 to 10000 years BP: herbivore physiologies and palaeoenvironmental reconstruction. Palaeogeog Palaeocl 163:33-47.

Inizian M-L, Roche H, Tixier J. 1992. Technology of Knapped Stone. Meudon: CREP.

Janis CM, 1990. The correlation between diet and dental wear in herbivorous mammals, and its relationship to the determination of diets of extinct species.In: Boucot AJ, editor. Evolutionary paleobiology of behavior and coevolution. Amsterdam: Elsevier Science. p 241-259.

Jaubert J, Hublin JJ, Soressi M, McPherron SP, Bailey S, Bordes JG, Claud E, Mallye JB, Michel A, Niclot M, Rendu 
W, Richards MP, Richter D, Roussel M, Steele T, Taylor G, Texier JP, 2008. La fin du Paléolithique moyen et le début du Paléolithique supérieur à Jonzac (Charente-Maritime): premiers résultats des campagnes 2004-2006.In: Jaubert J, Bordes JG, Ortega I, editors. Les sociétés Paléolithiques d'un grand Sud-Ouest: nouveaux gisements, nouvelles méthodes, nouveaux résultats. Paris: Société Préhistorique française. $\mathrm{p}$ $203-244$.

Jaubert J, Kervaso B, Bahain JJ, Brugal JP, Chalard P, Falguères C, Jarry M, Jeannet M, Lemorini C, Louchard A, Maksud F, Mourre V, Quinif Y, Thiebaut C. 2005. Coudoulous I (Tour-de-Faure, Lot), site du Pléistocène moyen en Quercy : bilan pluridisciplinaire.In: Molines N, Moncel MH, Monnier JL, editors. Les premiers peuplements en Europe : Données récentes sur les modalités de peuplement et sur le cadre chronostratigraphique, géologique et paléogéographique des industries du Paléolithique ancien et moyen en Europe (Rennes, 2225 septembre 2003). Oxford: Brit Archaeol Rep. p 227-252.

Jaubert J, Lorblanchet M, Laville H, Slott-Moller R, Turq A, Brugal JP. 1990. Les Chasseurs d'Aurochs de La Borde. Paris: Editions de la Maison des Sciences de l'Homme.

Jim S, Jones V, Ambrose SH, Evershed RP. 2006. Quantifying dietary macronutrient sources of carbon for bone collagen biosynthesis using natural abundance stable carbon isotope analysis. Brit J Nutr 95:1055-1062.

Kahlke RD. 1992. Repeated immigration of Saiga into Europe.In: Von Koenigswald W, Werdelin L, editors. Mammalian migration and dispersal events in the European Quaternary. Frankfurt: Courier Forschungsinstitut Senckenberg. p 187-195.

Kahlke RD. 1999. The history of the origin, evolution and dispersal of the late pleistocene mammuthus-coelodonta faunal complex in Eurasia (large mammals). Rapid City, SD: Fenske.

Kaidonis JA. 2008. Tooth wear: the view of the anthropologist. Clin Oral Invest 12 (Suppl 1):21-26.

Kaifu Y, Kasai K, Townsend GC, Richards LC. 2003. Tooth wear and the "design" of the human dentition: a perspective from evolutionary medicine. Yearb Phys Anthropol 46:47-61.

Katzenberg MA, 2000. Stable istope analysis: a tool for studying past diet, demography and life history.In: Katzenberg MA, Saunders SR, editors. Biological Anthropology of the Human Skeleton. New York: Willey-Liss. p 305-328.

Kay RF, Hiiemae KM. 1974. Jaw movement and tooth use in recent and fossil primates. Am J Phys Anthropol 40:227-256.

Kelly RL. 1995. The foraging spectrum. Diversity in HunterGatherer Lifeways. Washington DC: Smithsonian Institution Press.

Kindler L. 2007. Die rolle von raubtieren in der einnischung und subsistenz jungpleistozäner Neandertaler e archozoologie und taphonomie der mittelpaläolithischen fauna aus der Balver Höhle (Westfalen). Ph.D. Thesis unpublished. Mainz: Mainz University.

Krause J, Orlando L, Serre D, Viola B, Prüfer K, Richards MP, Hublin JJ, Hänni C, Derevianko AP, Pääbo S. 2007. Neanderthals in central Asia and Siberia. Nature 449:902-904.

Kuhnlein HV, Receveur O. 2007. Local cultural animal food contributes high levels of nutrients for Arctic Canadian indigenous adults and children. J Nutr 137:1110-1114.

Kullmer O, Benazzi S, Fiorenza L, Schulz D, Bacso S, Winzen O. 2009. Technical Note: occlusal fingerprint analysis: quantification of tooth wear pattern. Am J Phys Anthropol 139:600 606.

Lalueza C, Pérez-Pérez A, Chimenos E, Maroto J, Turbón D. 1993. Estudi radiogràfic i microscòpic de la mandíbula de Banyoles: patologies I estat de conservació.In: Maroto J, editor. La mandíbula de Banyoles en el context dels fossils humans del Pleistocè. Girona: Centre d'Investigacions Arqueológiques. p 135-144.

Lalueza C, Pérez-Pérez A, Turbón D. 1996. Dietary inferences through buccal microwear analysis of Middle and Upper Pleistocene human fossils. Am J Phys Anthropol 100:367387.
Lalueza Fox C, Frayer DW. 1997. Non-dietary marks in the anterior dentition of the Krapina Neanderthals. Int J Osteoarchaeol 7:133-149.

Lalueza Fox C, Pérez-Pérez A. 1993. The diet of the Neanderthal child Gibraltar 2 (Devil's Tower) through the study of the vestibular striation pattern. J Hum Evol 24:29-41.

Langejans GHJ. 2011. Remains of the day-preservation of organic micro-residues on stone tools. J Archaeol Sci 37:971985.

Laplace G. 1964. Essai de typologie systématique. Ferrara: Annali dell'Università di Ferrara, sez. XV I (suppl I. II).

Lebel S, Trinkaus E. 2001. A carious Neandertal molar from the Bau de l'Aubesier, Vaucluse, France. J Archaeol Sci 28: $555-557$.

Lee Thorp J, Sponheimer M. 2006. Contributions of biogeochemistry to understand hominin dietary ecology. Yearb Phys Anthropol 131:131-148.

Lee-Thorp JA. 2008. On isotopes and old bones. Archaeometry 50:925-950.

Leroi-Gourhan A. 1943. L' Homme et la Matière. Paris: Albin Michel.

Leroi-Gourhan A. 1964. Le Geste et la Parole. I, Technique et language. Paris: Albin Michel.

Lester CW, Shapiro HL. 1968. Vertebral arch defects in the lumbar vertebrae of prehistoric American Eskimos. Am J Phys Anthropol 28:43-48.

Lev E, Kislev ME, Bar-Yosef O. 2005. Mousterian vegetal food in Kebara Cave, Mt. Carmel. J Archaeol Sci 32:475-484.

Lieberman DE, Shea JJ. 1994. Behavioral differences between archaic and modern humans in the Levantine Mousterian. Am Anthropol 96:300-332.

Linse AR. 1992. Is bone safe in a shell midden?In: Stein JK, editor. Deciphering a shell midden. San Diego: Academic Press. p 327-345.

Lisiecki LE, Raymo ME. 2005. A Pliocene-Pleistocene stack of 57 globally distributed benthic $\mathrm{d}^{18} \mathrm{O}$ records. Paleoceanography 20 doi:10.1029/2004PA001071.

Lombard M, Wadley L. 2007. The morphological identification of microresidues on stone tools using light microscopy: progress and difficulties based on blind tests. J Archaeol Sci 34: $155-165$.

Longin R. 1971. New method of collagen extraction for radiocarbon dating. Nature 230:241-242.

Loy TH, Spriggs M, Wickler S. 1992. Direct evidence for human use of plants 28,000 years ago: starch residues on stone artefacts from the northern Solomon Islands. Antiquity 66:898912.

Lucas PW, Omar R, Al-Fadhalah K, Almusallam AS, Henry AG, Michael S, Thai LR, Watzke J, Strait DS, Atkins AG. 2013. Mechanisms and causes of wear in tooth enamel: implications for hominin diets. J R Soc Interface 10:20120923.

Lutz J. 1984. Calcium balance and acid-base status of women as affected by increased protein intake and by sodium bicarbonate ingestion. Am J Clin Nutr 39:281-288.

Lyman RL. 1994. Vertebrate Taphonomy. Cambridge: Cambridge University Press. p 552.

Lyman RL. 2008. Quantitative Paleozoology. Cambridge: Cambridge University Press. p 348.

Madella M, Alexandre A, Ball T. 2005. International code for phytolith nomenclature 1.0. Ann Bot 96:253-260.

Madella M, Jones MK, Goldberg P, Goren Y, Hovers E. 2002. The exploitation of plant resources by Neanderthals in Amud Cave (Israel): the evidence from phytolith studies. J Archaeol Sci 29:703-719.

Maier W, Schneck G. 1981. Konstruktionsmorphologische untersuchungen am gebiß der hominoiden Primaten. Z Morphol Anthropol 72:127-169.

Mann AE. 1981. Diet and human evolution.In: Harding RSO, Teleki G, editors. Omnivorous Primates: gathering and hunting in human evolution. New York: Columbia University Press. p 10-36.

Mann N. 2000. Dietary lean red meat and human evolution. Eur J Nutr 39:71-79. 
Marean CW. 2005. From the tropics to the colder climates: contrasting faunal exploitation adaptations of modern humans and Neanderthals. In: d'Errico F, Backwell L, editors. From tools to symbols: from early hominids to humans. Johannesburg: Witwatersrand University Press. p 333-371.

Martínez Valle R. 1996. Fauna del Pleistoceno superior en el País Valenciano: aspectos económicos, huella de manipulación y valoración paleoambiental. $\mathrm{PhD}$ thesis unpublished, Universitat de València.

Massey FP, Ennos AR, Hartley SE. 2007a. Grasses and the resource availability hypothesis: the importance of silicabased defences. J Ecol 95:414-424.

Massey FP, Ennos AR, Hartley SE. 2007b. Herbivore specific induction of silica-based plant defences. Oecologia 152:677683.

Massey FP, Hartley SE. 2006. Experimental demonstration of the antiherbivore effects of silica in grasses: impacts on foliage digestibility and vole growth rates. Proc R Soc B 273:22992304.

McDermott F, Grün R, Stringer CB, Hawkesworth CJ. 1993. Mass-spectrometric U-series dates for Israeli Neanderthal/ early modern hominid sites. Nature 363:252-255.

Minagawa M, Wada E. 1984. Stepwise enrichment of ${ }^{15} \mathrm{~N}$ along food chains: further evidence and the relation between ${ }^{15} \mathrm{~N}$ and animal age. Geochim Cosmochim Acta 48:1135-1140.

Molnar S. 1972. Tooth wear and culture: a survey of tooth functions among some prehistoric populations. Curr Anthropol 13: $511-526$.

Molnar S, Molnar IM, 1985. The prevalence of enamel hypoplasia among the Krapina Neandertals. Am Anthropol 87:536549 .

Naito YI, Chikaraishi Y, Ohkouchi N, Drucker DG, Bocherens H. 2013. Nitrogen isotopic composition of collagen amino acids as an indicator of aquatic resource consumption: insights from Mesolithic and Epipalaeolithic archaeological sites in France. World Archaeol 45:338-359.

Nehlich O, Boric D, Stefanovic S, Richards MP. 2010. Sulphur isotope evidence for freshwater fish consumption: a case study from Danube Gorges, SE Europe. J Archaeol Sci 37:11311139 .

Nielsen-Marsh CM, Richards MP, Hauschka PV, Thomas-Oates JE, Trinkaus E, Pettitt PB, Karavanić I, Poinar H, Collins MJ. 2005. Proc Natl Acad Sci USA 102:4409-4413.

Niven L, Steele TE, Rendu W, Mallyde J-B, McPherron SP, Soressi M, Jaubert J, Hublin J-J. 2012. Neandertal mobility and large-game hunting: the exploitation of reindeer during the Quina Mousterian at Chez-Pinaud Jonzac (Charente-Maritime, France). J Hum Evol 63:624-635.

Oakley KP, Andrews A, Keeley LH, Clark JD. 1977. A reappraisal of the Clacton spear point. Proc Prehist Soc 43:13-30.

O'Connell TC, Kneale CJ, Tasevska N, Kuhnle GGC. 2012. The diet-body offset in human nitrogen isotopic values: a controlled dietary study. Am J Phys Anthropol 149:426-434.

Ogilvie MD, Curran BK, Trinkaus E. 1989. Prevalence and patterning of dental enamel hypoplasia among the Neandertals. Am J Phys Anthropol 79:25-41.

O'Leary M. 1981. Carbon isotope fractionation in plants. Phytochemistry 20:553-567.

Palmarelli A, Palombo MR. 1981. Un cranio di et al. (Blumenbach) (Rhinocerotidae) del Pleistocene superiore del Monte Circeo (Lazio meridionale). B Serv Geo Ital 102:281-312.

Palombo MR, Ferretti MP. 2005. Elephant fossil record from Italy: knowledge, problems, and perspectives. Quaternary Int 126-128:107-136.

Patou-Mathis M. 2000. Neanderthal subsistence behaviours in Europe. Int J Osteoarchaeol 10:379-395.

Pearsall DM. Formation Processes of Pollen and Phytoliths. In: Marston JM, d' Alpoim Guedes J, Warinner C, editors. Method and Theory in Paleoethnobotany. University Press of Colorado. In press.

Pearsall DM. 2000. Paleoethnobotany: a handbook of procedures. San Diego: Academic Press.

Pérez-Pérez A, Espurz V, Bermúdez de Castro JM, de Lumley MA, Turbón D, 2003. Non-occlusal dental microwear variabili- ty in a sample of Middle and Late Pleistocene human populations from Europe and the Near East. J Hum Evol 44:497-513.

Pérez-Pérez A, Lalueza C, Turbón D. 1994. Intraindividual and intragoup variability of of buccal tooth striation pattern. Am J Phys Anthropol 94:175-187.

Pérez Ripoll M. 1977. Los mamíferos del yacimiento musteriense de Cova Negra. Servicio de Investigación Prehistórica de la Diputación de Valencia, Serie TrabajosVarios 53, Valencia. p 147.

Pérez Ripoll M, Morales JV, Sanchis A, Aura JE, Sarrión I. 2010. Presence of the genus Cuon in upper Pleistocene and initial Holocene sites of the Iberian Peninsula. New remains identified in archaeological contexts of the Mediterranean region. J Archaeol Sci 37:437-450.

Peterson BJ, Fry B. 1987. Stable isotopes in ecosystem studies. Annu Rev Ecol Syst 18:293-320.

Pettitt P. 2000. Neanderthal lifecycles: development and social phases in the lives of the last archaics. World Archaeol 31: 351-366.

Petzke KJ, Boeing H, Metges CC. 2005. Choice of dietary protein of vegetarians and omnivores is reflected in their hair protein C-13 and N-15 abundance. Rapid Commun Mass Spectrom 19:1392-1400.

Picin A. 2012. Technological change and hunting behavior during the Middle Paleolithic.In: Cascalheira J, Gonçalves C, editors. Actas das IV Jornadas de Jovens em Investigação Arqueológica - JIA 2011. Faro: Tipografia Tavirense, Lda. p 185-191.

Picin A, Peresani M, Falguères C, Gruppioni G, Bahain JJ 2013. San Bernardino Cave (Italy) and the appearance of Levallois technology in Europe: results of a radiometric and technological reassessment. PloS one 8:e76182.

Piperno DR. 2006. Phytoliths: a comprehensive guide for archaeologists and paleoecologists. Lanham, Maryland: AltaMira Press.

Piperno DR, Holst I. 1998. The presence of starch grains on prehistoric stone tools from the humid Neotropics: Indications of early tuber use and agriculture in Panama. J Arch Sci 25 765-776.

Piperno DR, Ranere AJ, Holst I, Hansell P. 2000. Starch grains reveal early root crop horticulture in the Panamanian tropical forest. Nature 407:894-897.

Piperno DR, Weiss E, Holst I, Nadel D. 2004. Processing of wild cereal grains in the Upper Paleolithic revealed by starch grain analysis. Nature 430:670-673.

Power RC, Salazar-García DC, Wittig RG, Henry AG. 2014. Assessing use and suitability of scanning electron microscopy in the analysis of microremains in dental calculus. J Archaeol Sci. 49:160-169.

Preiss J. 2009. Biochemistry and molecular biology of starch biosynthesis.In: BeMiller J, Whistler R, editors. Starch: chemistry and technology, 3rd ed. New York: Academic Press. p 83-148.

Puech PF. 1981. Tooth wear in La Ferrassie man. Curr Anthropol 22:424-430.

Raichlen DA, Armstrong H, Lieberman DE. 2011. Calcaneus length determines running economy: implications for endurance running performance in modern humans and Neandertals. J Hum Evol 60:299-308.

Rapp GJ, Mulholland SC. 1992. Phytolith systematics: emerging issues. New York: Plenum Press.

Ready E. 2010. Neandertal man the hunter: a history of Neandertal subsistence. Explor Anthropol 10:58-80.

Reichert ET. 1913. The differentiation and specificity of starches in relation to genera, species, etc. Washington, DC: The Carnegie Institution of Washington.

Reichert ET. 1919. A biochemic basis for the study of problems of taxonomy, heredity, evolution, etc., with especial reference to the starches and tissues of parent-stocks and hybrid-stocks and the starches and hemoglobins of varieties, species and genera. Washington, DC: The Carnegie Institution of Washington.

Rendu W, Costamagno S, Meignen L, Soulier MC. 2012. Monospecific faunal spectra in Mousterian contexts: Implications for social behavior. Quatern Int 247:50-58. 
Richards M, Harvati K, Grimes V, Smith C, Smith T, Hublin JJ, Karkanas P, Panagopoulou E, 2008a. Strontium isotope evidence of Neanderthal mobility at the site of Lakonis, Greece using laser-ablation PIMMS. J Archaeol Sci 35:12511256.

Richards MP, Hedges REM. 1999. Stable isotope evidence for similarities in the types of marine foods used by late mesolithic humans at sites along the Atlantic Coast of Europe. J Archaeol Sci 26:717-722.

Richards MP, Hedges REM. 2003. Variations in bone collagen $13 \mathrm{C}$ and $15 \mathrm{~N}$ values of fauna from Northwest Europe over the last 40,000 years. Palaeogeogr Palaeocl 193:261-267.

Richards MP, Pettitt PB, Trinkaus E, Smith FH, Karavanić I, Paunović M. 2000. Neanderthal diet at Vindija and Neanderthal predation: the evidence from stable isotopes. Proc Natl Acad Sci USA 97:7663-7666.

Richards MP, Schmitz R. 2008. Isotope evidence for the diet of the Neanderthal type specimen. Antiquity 82:553-559.

Richards MP, Taylor G, Steele T, McPherron SP, Soressi M, Jaubert J, Orschiedt J, Mallye JB, Rendu W, Hublin JJ. 2008b. Isotopic dietary analysis of a Neanderthal and associated fauna from the site of Jonzac (Charente-Maritime), France. J Hum Evol 55:179-185.

Richards MP, Trinkaus E. 2009. Isotopic evidence for the diets of European Neanderthals and early modern humans. Proc Natl Acad Sci USA 106:16034-16039.

Romero A, Ramírez-Rozzi FV, De Juan J, Pérez-Pérez A. 2013. Diet-related buccal dental microwear patterns in Central African pygmy foragers and Bantu-speaking farmer and pastoralist populations. PLoS One 8:e84804.

Rosell J, Blasco R, Fernández-Laso MC, Vaquero M, Carbonell E. 2012a. Connecting areas: faunal refits as a diagnostic element to identify synchronicity in the Abric Romaní archaeological assemblages. Quatern Int 252:56-67.

Rosell J, Blasco R, Huguet R, Cáceres I, Saladié P, Rivals F, Bennàsar $\mathrm{M}$, Bravo $\mathrm{P}$, Campeny $\mathrm{G}$, Esteban-Nadal $\mathrm{M}$, Fernández-Laso C, Gabucio M, Ibáñez N, Martín P, Muñoz L, Rodríguez-Hidalgo A. 2012b. Occupational patterns and subsistence strategies in level $\mathrm{J}$ of Abric Romaní.In: Carbonell i Roura E, editor. High resolution archaeology and Neanderthal behavior. Netherlands: Springer. p 313-372.

Rosen AM. 2003. Middle Paleolithic plant exploitation: the microbotanical evidence.In: Henry DO, editor. Neanderthals in the Levant: behavioral organization and the beginnings of human modernity. London: Continuum. p 156-171.

Rots V. 2009. The functional analysis of the Mousterian and Micoquian assemblages of Sesselfelsgrotte, Germany: Aspects of tool use and hafting in the European Late Middle Palaeolithic. Quartär 56:37-66.

Rots V. 2013. Insights into early Middle Palaeolithic tool use and hafting in Western Europe. The functional analysis of level IIa of the early Middle Palaeolithic site of Biache-SaintVaast (France). J Archaeol Sci 40:497-506.

Rudman D, DiFulco TJ, Galambos JT, Smith RB, Salam AA, Warren WD. 1973. Maximal rates of excretion and synthesis of urea in normal and cirrhotic subjects. J Clin Invest 52: $2241-2249$

Ruff CB. 1994. Morphological adaptation to climate in modern and fossil hominids. Yearb Phys Anthropol 37:65-107.

Rus I, Vega Toscano G. 1984. El yacimiento de Arriaga II: problemas de una definición actual de los suelos de ocupación, Primeras Jornadas de Metodología e Investigación Prehistórica (Soria, 1981). Ministerio de Cultura. P 387-404.

Sage RF, Wedin DA, Li M. 1999. The biogeography of $\mathrm{C}_{4}$ photosynthesis: patterns and controlling factors. In: Sage RF, Monson RK, editors. 2013. C4 Plant Biology. London: Academic Press. p 313-373.

Salazar-Garcia DC, Power RC, Sanchis Serra A, Villaverde V, Walker MJ, Henry AG. 2013. Neanderthal diets in central and southeastern Mediterranean Iberia. Quaternary Int 318: $3-18$

Salazar-García DC, Aura E, Olària C, Talamo S, Morales JV, Richards MP. 2014a. Isotope evidence for the use of marine resources in the Eastern Iberian Mesolithic. J Archaeol Sci 42:231-240.

Salazar-García DC, Richards MP, Nehlich O, Henry AG. 2014b. Dental calculus is not equivalent to bone collagen for isotope analysis: a comparison between carbon and nitrogen stable isotope analysis of bulk dental calculus, bone and dentine collagen from same individuals from the Medieval site of El Raval (Alicante,Spain). J Archaeol Sci 47:70-77.

Sanchis A. 2012. Los lagomorfos del Paleolítico medio en la vertiente mediterránea ibérica. Humanos y otros predadores como agentes de aporte y de alteración de los restos óseos en yacimientos arqueológicos. Serie de Trabajos Varios del Servicio de Investigación Prehistórica 115.

Sanchis A, Fernández Peris J. 2008. Procesado y consumo antrópico de conejo en la Cova del Bolomor (Tavernes de la Valldigna, Valencia). El nivel XVIIc (ca $350 \mathrm{ka}$ ). Complutum19:25-46.

Schoeninger MJ, De Niro MJ, Tauber H. 1983. Stable nitrogen isotope ratios of bone collagen reflect marine and terrestrial components of prehistoric human diet. Science 220:13811383 .

Schoeninger MJ, De Niro MJ. 1984. Nitrogen and carbon isotopic composition of bone collagen from marine and terrestrial animals. Geochim Cosmochim AC48:625-639.

Scott B, Ashton N. 2011. The early Middle Palaeolithic: the European context.In: Ashton N, Lewis SG, Stringer C, editors. The ancient human occupation of Britain. Amsterdam: Elsevier. p 91-112.

Scott RS, Teaford MF, Ungar PS. 2012. Dental microwear texture and Anthropoid diets. Am J Phys Anthropol 147:551579.

Scott RS, Ungar PS, Bergstrom TS, Brown CA, Childs BE, Teaford MF, Walker A. 2006. Dental microwear texture analysis: technical considerations. J Hum Evol 51:339-349.

Schreve DC. 2001. Differentiation of the British late Middle Pleistocene interglacials: the evidence from mammalian biostratigraphy. Quatern Sci Rev 20:1693-1705.

Schwarcz HP, Schoeninger MJ. 1991. Stable isotope analyses in human nutritional ecology. Yearb Phys Anthropol 34:283-321.

Sealy J. 2001. Body tissue chemistry and paleodiet.In: Brothwell DR, Pollard AM, editors. Handbook of Archaeological Sciences. Chichester: Wiley. p 269-279.

Seidemann J. 1966. Stärke-Atlas. Berlin: Paul Parey.

Semenov SA. 1964. Prehistoric Technology; an Experimental Study of the Oldest Tools and Artefacts from Traces of Manufacture and Wear. London: Cory, Adams \& Mackay.

Shannon JC, Garwood DL, Boyer CD. 2009. Genetics and physiology of starch development.In: BeMiller J, Whistler R, editors. Starch: chemistry and technology, 3rd ed. New York: Academic Press. p 23-82.

Shea JJ. 2007. Behavioral differences between middle and upper Paleolithic Homo sapiens in the East Mediterranean Levant. J Anthropol Res 63:449-480.

Sinclair HM. 1953. The diet of Canadian Indians and Eskimos. Proc Nutr Soc 12: 69-82.

Sirocko F, Claussen M, Litt T, Sánchez Goñi MF, Berger A, Boettger T, Diehl M, Desprat S, Delmonte B, Degering D, Frechen M, Geyh M, Groeger M, Kageyama M, Kaspar F, Kühl N, Kubatzki C, Lohmann G, Loutre MF, Müller U, Rein B, Rosendahl W, Roucoux K, Rousseau DD, Seelos K, Siddall M, Scholz D, Spötl C, Urban B, Vautravers M, Velichko A, Wenzel S, Widmann M, Wünnemann B. 2007. Chronology and climate forcing of the last four interglacials.In: Siroko F, Claussen M, Sánchez Goñi MF, Litt T, editors. The climate of past interglacials. Amsterdam: Elsevier. p 597-614.

Sistiaga A, Mallol C, Galván B, Summons RE. 2014. The Neanderthal meal: a new perspective using faecal biomarkers. Plos One 9:e101045.

Sivak MM, Preiss J. 1998. Starch: Basic science to biotechnology.In: Taylor SL editor. Advances in food and nutrition research. California: Academic Press. p 1-199.

Skinner M. 1997. Dental wear in immature Late Pleistocene European hominines. J Archaeol Sci 24:677-700. 
Smith BH. 1984. Patterns of molar wear in hunter-gatherers and agriculturists. Am J Phys Anthropol 63:39-56.

Smith FH, Trinkaus E, Pettitt PB, Karavanic I, Paunovic M. 1999. Direct radiocarbon dates for Vindija G1 and Velika Pecina Late Pleistocene hominid remains. Proc Natl Acad Sci USA 96:12281-12286.

Smith GM. 2012. Hominin-carnivore interaction at the lower palaeolithic site of boxgrove, UK. J Taphonomy 10:373-394.

Smith GM. 2013. Taphonomic resolution and hominin subsistence behaviour in the Lower Palaeolithic: differing data scales and interpretive frameworks at Boxgrove and Swanscombe (UK). J Archaeol Sci 40:3754-3767.

Smith CI, Fuller BT, Choy K, Richards MP. 2009. A three-phase liquid chromatographic method for $\delta^{13} \mathrm{C}$ analysis of amino acids from biological protein hydrolysates using liquid chromatography-isotope ratio mass spectrometry. Anal Biochem 390:165-172.

Soffer O. 1994. Ancestral lifeways in Eurasia: the middle and upper Paleolithic records.In: Nitecki M, Nitecki D, editors. Origin of Anatomically Modern Humans. New York: Plenum. p 101-119.

Sorensen MV, Leonard WR. 2001. Neandertal energetics and foraging efficiency. J Hum Evol 40:483-495.

Soto E. 1980. Artiodáctilos y Proboscidios de los yacimientos de Áridos de Arganda (Madrid).In: Santonja M, López N, PérezGonzález A, editors. Ocupaciones achelenses en el valle del Jarama (Arganda, Madrid), Arqueología y Paleoecología I. Madrid: Diputación Provincial de Madrid. p 207-229.

Speth JD. 2010. The paleoanthropology and archaeology of biggame hunting. New York: Springer.

Speth JD. 2012. Middle Paleolithic subsistence in the Near East: zooarchaeological perspectives - past, present, and future. Before Farming 2012/2 article 1:1-45.

Speth JD, Spielmann KA. 1983. Energy source, protein metabolism, and hunter-gatherer subsistence strategies. J Anthropol Archaeol 2:1-31.

Sponheimer M, Lee-Thorp J. 2007. Hominin palaeodiets: the contribution of stable isotopes.In: Henke W, Tattersall I, editors. Handbook of paleoanthropology. Berlin: Springer-Verlag. p 555-586.

Sponheimer M, Robinson TF, Ayliffe LK, Roeder BL, Hammer J, Passey BH, West A, Cerling TE, Dearing MD, Ehleringer JR. 2003. Nitrogen Isotopes in mammalian herbivores: hair $\delta^{15} \mathrm{~N}$ values from a controlled feeding study. Int J Osteoarchaeol 13:80-87.

Steegmann AT, Cerny JRF, Holliday TW. 2002. Neandertal cold adaptation: physiological and energetic factors. Am J Hum Biol 14:566-583.

Stiner MC. 2005. The Faunas of Hayonim Cave (Israel): A 200,000-year record of Paleolithic diet, demography and society. Cambridge: Peabody Museum of Archaeology and Ethnology.

Stiner MC. 2013. An unshakable Middle Paleolithic? Trends versus conservatism in the predatory niche and their social ramifications. Curr Anthropol 54:S288-S304.

Stiner MC, Munro ND, Surovell TA. 2000. The tortoise and the hare: small game use, the broad spectrum evolution and Palaeolithic demography. Curr Anthropol 41:39-73.

Stringer CB, Finlayson JC, Barton RNE, Fernández-Jalvo Y, Cáceres I, Sabinh RC, Rhodes EJ, Currant AP, RodríguezVidal J, Giles-Pacheco F, Riquelme-Cantal JA. 2008. Neanderthal exploitation of marine mammals in Gibraltar. Proc Natl Acad Sci USA 105:14319-14324.

Svensson A, Andersen KK, Bigler B, Clausen HB, Dahl-Jensen D, Davies SM, Johnsen SJ, Muscheler R, Rasmussen SO, Röthlisberger R, Steffensen JP, Vinther BM. 2006. The Greenland Ice Core Chronology 2005, 15-42 ka. Part 2: comparison to other records. Quatern Sci Rev 25:3258-3267.

Szpak P. 2011. Fish bone chemistry and ultrastructure: implication for taphonomy and stable isotope analysis. J Archaeol Sci 38:3358-3372.

Thieme H. 1997. Lower Palaeolithic hunting spears from Germany. Nature 385:807-810.

Thieme H, Veil S. 1985. Neue Untersuchungen zum eemzeitlichen Elefanten-Jagdplatz Lehringen. Ldkr. Verden: Die Kunde 36:11-58.
Tillier AM, Arensburg B, Rak Y, Vandermeersch B. 1995. Middle Palaeolithic dental caries: new evidence from Kebara (Mount Carmel, Israel). J Hum Evol 29:189-192.

Torrence R, Barton H. 2006. Ancient starch research. Walnut Creek, California: Left Coast Press.

Torrence R, Wright R, Conway R. 2004. Identification of starch granules using image analysis and multivariate techniques. J Archaeol Sci 31:519-532

Toussaint M, Olejniczak AJ, El Zaatari S, Cattelain P, Flas D, Letourneux C, Pirson S. 2010. The Neandertal lower right deciduous second molar from Trou de l'Abîme at Couvin, Belgium. J Hum Evol 58:56-67.

Trinkaus E. 1981. Neanderthal limb proportions and cold adaptation.In: Stringer CB, editor. Aspects of human evolution. London: Taylor and Francis. p 187-224.

Trinkaus E. 1983. The Shanidar Neandertals. New York: Academic Press.

Trinkaus E. 1986. The Neandertals and modern human origins. Ann Rev Anthropol 15:193-218.

Trinkaus E. 1995. Neanderthal mortality patterns. J Archaeol Sci 22:121-142.

Trinkaus E. 2012. Neandertals, early modern humans, and rodeo riders. J Archaeol Sci 39:3691-3693.

Trinkaus E, Smith RJ, Lebel S. 2000. Dental caries in the Aubesier 5 Neandertal primary molar. J Archaeol Sci 27: 1017-1021.

Turner II CG, Cadien JD. 1969. Dental chipping in Aleuts, Eskimos and Indians. Am J Phys Anthropol 31:303-310.

Tzedakis PC. 1994. Vegetation change through glacialinterglacial cycles: A long pollen sequence perspective. Philos Trans R Soc Lond B Biol Sci 345:403-432.

Tzedakis PC. 2005. Towards an understanding of the response of southern European vegetation to orbital and suborbital climate variability. Quatern Sci Rev 24:1585-1599.

Ukraintseva VV. 2013. Mammoths and the Environment. Cambridge: Cambridge University Press.

Ulhaas L, Kullmer O, Schrenk F. 2007. Tooth wear diversity in early hominid molars: a case study.In Bailey SE, Hublin JJ, editors. Dental perspectives on human evolution: state of the art research in dental paleoanthropology. The Netherlands: Springer. p 369-390.

Ungar PS, Brown CA, Bergstrom TS, Walker A. 2003. Quantification of dental microwear by tandem scanning confocal microscopy and scale-sensitive fractal analyses. Scanning 25:185-193.

Valensi P. 2000. The archaeozoology of Lazaret Cave (Nice, France). Int J Osteoarchaeol 10:357-367.

Valensi P, Psathi E. 2004. Faunal exploitation during the Middle Palaeolithic in south-eastern France and north-western Italy. Int J Osteoarchaeol 14:256-272.

Van Andel T.H. \& Tzedakis P.C., 1996. Paleolithic landscapes of Europe and environs, 150,000-25,000 years ago: an overview. Quatern Sci Rev 15:481-500.

Van der Merwe NJ, Vogel JC. 1978. ${ }^{13} \mathrm{C}$ content of human collagen as a measure of prehistoric diet in Woodland North America. Nature 276:815-816.

Van Klinken GJ. 1999. Bone collagen quality indicators for palaeodietary and radiocarbon measurements. J Archaeol Sci 26:687-695.

Vaquero M. 2008. The history of stones: behavioural inferences and temporal resolution of an archaeological assemblage from the Middle Palaeolithic. J Archaeol Sci 35:3178-3185.

Vaquero M, Chacón M, Cuartero F, García-Antón MD, Gómez de Soler B, Martínez K. 2012. The Lithic Assemblage of Level J.In: Carbonell i Roura E, editor. High Resolution Archaeology and Neanderthal Behavior. Netherlands: Springer. p 189-311.

Villa P, Boscato P, Ranaldo F, Ronchitelli A. 2009. Stone tools for the hunt: points with impact scars from a Middle Paleolithic site in southern Italy. J Archaeol Sci 36:850-859.

Villa P, Lenoir M. 2009. Hunting and hunting weapons of the Lower and Middle Paleolithic of Europe.In: Hublin JJ, Richards M, editors. The evolution of hominin diets. The Netherlands: Springer. p 59-85. 
Villa P, Soto E, Santonja M, Pérez-González A, Mora R, Parcerisas J, Sesé C, 2005. New data from Ambrona: closing the hunting versus scavenging debate. Quatern Int 126-128:223-250.

Von Koenigswald W. 2007. Mammalian faunas from the interglacial periods in Central Europe and their stratigraphic correlation. Dev Quatern Sci 7:445-454.

Von Koenigswald W. 2011. Discontinuities in the faunal assemblages and early human populations of central and western Europe during the Middle and Late Pleistocene.In: Condemi $\mathrm{S}$, Weniger GC, editors. Continuity and discontinuity in the peopling of Europe. The Netherlands: Springer. p 101-112.

Walker MJ, Zapata J, Lombardi AV, Trinkaus E. 2011. New evidence of dental pathology in 40,000-year-old Neandertals. J Dent Res 90:428-432.

Wallace JA. 1975. Did La Ferrassie I use his teeth as a tool? Curr Anthropol 16:393-401.

Warinner C, Matias Rodrigues JF, Vyas R, Trachsel C, Shved N, Grossman J, Radini A, Hancock Y, Tito RY, Fiddyment S, Speller C, Hendy J, Charlton S, Luder HU, Salazar-García DC, Eppler E, Seiler R, Hansen L, Samaniego Castruita JA, Barkow-Oesterreicher S, Teoh KY, Kelstruo C, Olsen JV, Nanni P, Kawai T, Willerslev E, Von Mering C, Lewis CM, Collins M., Gilbert MTP, Rühli F, Cappellini E. 2014. Pathogens and host immunity in the ancient human oral cavity. Nat Genet 46:336-344.

Warinner C, Robles García N, Tuross N. 2013. Maize, beans and the floral isotopic diversity of highland Oaxaca, Mexico. J Archaeol Sci 40:868-873.
Weinstein KJ. 2008. Thoracic morphology in Near Eastern Neandertals and early modern humans compared with recent modern humans from high and low altitudes. J Hum Evol 54: 287-295.

Wei Wo CK, Draper HH. 1975. Vitamin E status of Alaskan Eskimos. Am J Clin Nutr 28:808-813.

Winterhalder B, Smith EA. 2000. Analyzing adaptive strategies: human behavioral ecology at twenty-five. Evol Anthropol 9:51-72.

Wohlfarth B, Veres D, Ampel L, Lacourse T, Blaauw M, Preusser F, Andrieu-Ponel V, Kéravis D, Lallier-Vergés E, Björck S, Davies S, de Beaulieu J-L, Risberg J, Hormes A, Kasper HU, Possnert G, Reille M, Thouveny N, Zander A. 2008. Rapid ecosystem response to abrupt climate changes during the last glacial period in western Europe, 40-16 ka. Geology 36:407-410.

Wolff EW, Chappellaz J, Blunier T, Rasmussen SO, Svensson A. 2010. Millennial-scale variability during the last glacial: The ice core record. Quatern Sci Rev 29:2828-2838.

Wolpoff MH. 1996. Human evolution. New York: McGraw-Hill.

Wood B, Schroer K. 2012. Reconstructing the diet of an extinct hominin taxon: the role of extant primate models. Int J Primatol 33:716-742.

Yravedra J, Panera J, Rubio-Jara S, Manzano I, Expósito A, Pérez-González A, Soto E, López-Recio M. 2014. Neanderthal and Mammuthus interactions at EDAR Culebro 1 (Madrid, Spain). J Archaeol Sci 42:500-508.

Yravedra J, Rubio-Jara S, Panera J, Uribelarrea D, PérezGonzález A. 2012. Elephants and subsistence. Evidence of the human exploitation of extremely large mammal bones from the Middle Palaeolithic site of PRERESA (Madrid, Spain). J Archaeol Sci 39:1063-1071. 